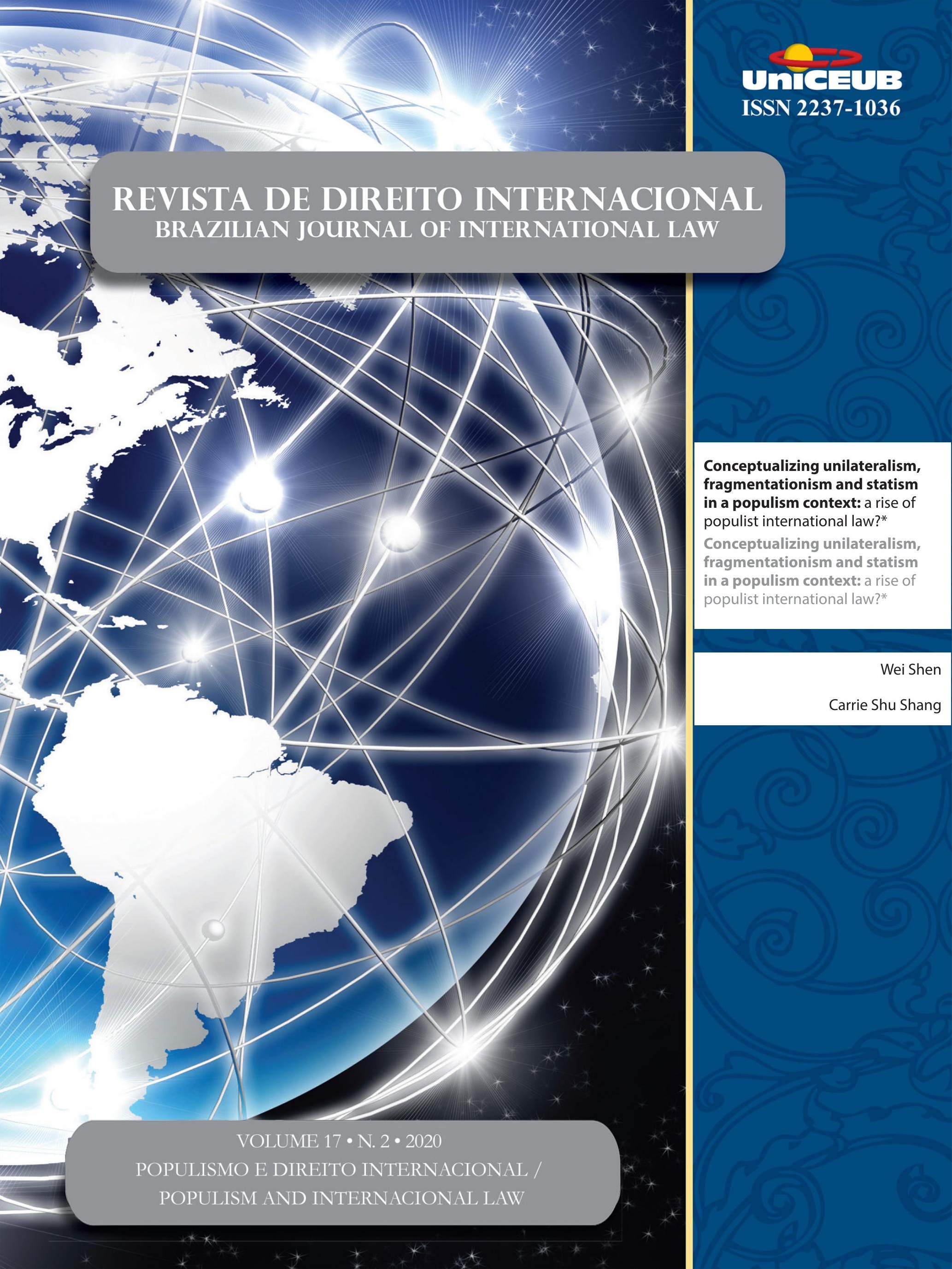




\section{Sumário}

I. CRônicas

A Favor de uma Corte Latino-Americana de Justiça ..................................................... 3 Nitish Monebhurrun

Sobre A SOluÇão JUdicial de CONTROvérsias Na AMÉRICA LATINA 7 Lucas Carlos Lima

A Favor de uma Corte Latino-Americana de Justiça - Uma Reação sobre a Legalidade e A Legitimidade De Seu Desenho Institucional............................................................15

Arthur Roberto Capella Giannattasio

O Estudo do Direito Internacional sob uma Nova Perspectiva: Nossa Experiência na Philip C. Jessup International Moot Court Competition............................................20 Ana Vitória Muniz Bokos, Igor Medeiros Maia, Jefferson Seidy Sonobe Hable, Gabriel de Oliveira Borba, Gilda Nogueira Paes Cambraia e Nayara Lima Rocha Da Cruz

Revisión de laudos de arbitrajes de inversión 2019: I Encuentro Anual (Santiago de

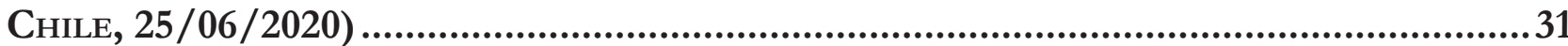
Andrés Delgado Casteleiro e Ivette Esis

II. Dossiê: Populismo e Direito Internacional / Populism and Internatio-

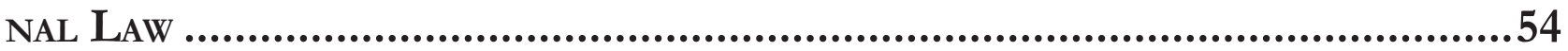

Editorial: Populism and International Law: Global South Perspectives .56 Lucas Lixinski e Fabio Morosini

Editorial: Populismo e Direito Internacional: Perspectivas do Sul Global .61 Lucas Lixinski e Fabio Morosini 
Between Science and populism: the Brazilian Response to COVID-19 from the Perspective of the legal determinants of Global Health

Deisy de Freitas Lima Ventura e Jameson Martins

Populism, ENVIronmental LAW, AND THE POST-PANDEMiC ORDER Alessandra Lehmen

Populism and the Evangelical church in Latin America: how anti-LGBTI forces TRIED TO STOP THE COLOMBIAN PEACE AGREEMENT Julia Assmann de Freitas Macedo e Fabrízio Conte Jacobucci

“Deus EM Davos": o Direito INTERnACIONAL ENTRE REACIONÁRIOS E NEOLIBERAIS NO GOVERNO BOLSONARO 121

Lucas Tasquetto e João Roriz

CHINESE POPULISM IN THE 1920s, EXTRATERRITORIALITY AND INTERNATIONAL LAW 139 Wanshu Cong

CONCEPTUALIZING UNILATERALISM, FRAGMENTATIONISM AND STATISM IN A POPULISM CONTEXT: A RISE OF POPULIST INTERNATIONAL LAW? 162 Wei Shen e Carrie Shu Shang

AUTONOMÍA ADMINISTRATIVA SIN AUTONOMÍA POLÍTICA: LA APLICACIÓN DEL MODELO "UN PAÍS dos SISTEMAs" eN HoNg Kong 186 Juan Enrique Serrano Moreno

III. Artigos sobre outros temas...................................................... 197

Um TWAiler entre nós? As contribuições de Celso Duvivier de Albuquerque Mello PARA O DIREITO INTERNACIONAL (CRÍTICO) NO BRASIL .................................................... 199

Fabio Morosini e Matheus Leichtweis

DEMOCRACIES IN DANGER: ARE JUDICIAL DIALOGUES MEANS TO REFRAIN SETBACKS IN LATIN America?.

Melina Girardi Fachin e Bruna Nowak 


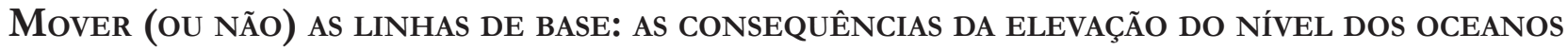
SOBRE AS ZONAS MARÍTIMAS DOS PEQUENOS ESTADOS INSULARES EM DESENVOLVIMENTO E AS ALTERNATIVAS JURÍDICAS PARA REDUZIR SEUS IMPACTOS

Alexandre Pereira da Silva

A mineração em águas profundas no Pacífico 263 Pierre-Jean Bordahandy

Dual Nationality and International Law in times of Globalization. Challenges and Opportunities for Consular Assistance and Diplomatic Protection in RECENT CASES. 288

Walter Arevalo-Ramirez e Robert Joseph Blaise Maclean

Expulsion of aliens: the application of International Law by Chilean Superior Courts 309

Regina Ingrid Díaz Tolosa

O TIPO PENAL BRASILEIRO DE PROMOÇÃo DE MIGRAÇÃO ILEGAL E O PRINCÍPIO DA NÃO CRIMINALIZAÇÃo DA MOBILIDADE HUMANA

Regina Cândido Lima e Silva Santos e Deilton Ribeiro Brasil

INDICADORES TRANSNACIONAIS DE CORRUPÇÃO AMBIENTAL: A OPACIDADE NA TRANSPARÊNCIA INTERNACIONAL

Márcio Ricardo Staffen

SubTRAÇÃo INTERNACIONAL DE CRIANÇAS: ANÁLISE DAS EXCEÇÕES AO RETORNO IMEDIATO DO MENOR À RESIDÊNCIA HABITUAL E CRÍTICA AO ENQUADRAMENTO DA VIOLÊNCIA DOMÉSTICA COMO FLEXIBILIDADE PERMISSIVA

Vivian Daniele Rocha Gabriel

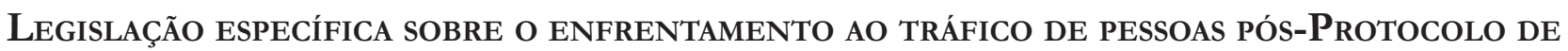
Palermo (2000): análise do Estado de Moçambique 383

Mercia Cardoso de Souza, Guirino Dinis José Nhatave e Francisco Horácio da Silva Frota 
IV. Artigos traduzidos

DIREITO INTERNACIONAL DO RECONHECIMENTO

Emmanuelle Tourme-Jouannet e Tradutor: Ademar Pozzatti Junior

V. RESENHAS

Fabio Costa Morosini, Gabriel Lee Mac Fadden Santos, Valentina Fonseca da Luz e Vinicius Tejadas Maia 


\title{
Conceptualizing unilateralism, fragmentationism and statism in a populism context: a rise of populist international law?*
}

\author{
Conceptualizing unilateralism, \\ fragmentationism and statism in a populism \\ context: a rise of populist international law?
}

Wei Shen **

Carrie Shu Shang***

\begin{abstract}
The rise of populist governments around the world has attracted a great deal of attention from international law scholars. The field of international law witnesses a range of studies analyzing recent populist movements and their impact on international law, in particular, in the fields of trade, environment, human rights and migration. However, existing literature focusing on the Global South is scant. Nonetheless, as populism is essentially linked to nativism, jingoism, and authoritarianism, the South countries need to be investigated as well, given their close association with nationalism and localism especially when they came to participate in the rule-of-law dialogues. This article fills the gap by offering some insights to the understanding of populism from three perspectives: behaviors, regimes and actors, and cautions that populism places global justice and rule of law at a high stake of risk.
\end{abstract}

Keywords: Populism. Unilateralism. Rule of Law. China. Global South.

\section{Resumo}

A ascensão de governos populistas em todo o mundo atraiu muita atenção de estudiosos do direito internacional. O campo do direito internacional testemunha uma série de estudos que analisam os movimentos populistas recentes e seu impacto no direito internacional, em particular, nos campos do comércio, do meio ambiente, dos direitos humanos e da migração. No entanto, a literatura existente com foco no Sul Global é escassa. Como o populismo está essencialmente ligado ao nativismo, chauvinismo e autoritarismo, os países do Sul também precisam ser investigados, dada sua estreita associação com o nacionalismo e o localismo, especialmente quando passaram a participar dos diálogos sobre o estado de direito. Este artigo busca contribuir ao preencher a lacuna, oferecendo alguns insights para a compreensão do populismo a partir de três perspetivas: comportamentos, regimes e atores, e advertências de que o populismo coloca a justiça global e o estado de direito em alto risco. 
Palavras-chave: Populismo. Unilateralismo. Estado de Direito. China. Sul Global

\section{Introduction}

Populism is a theme of the current global order. Populism, as a social phenomenon, is hard to define, let alone a legal definition. However, it is clear that the recent uptick in populism signals political, economic, social unrest and even legal disruption internationally. General consensus is that populism is viewed as a struggle between the people and the elites, ${ }^{1}$ as well as a backlash against the cultural, economic and legal effects of globalization. In light of the current social, political, and economic turmoil, rule of law also suffers from populism at both national and international levels.

The rise of populist governments around the world has attracted a great deal of attention from international law scholars. The field of international law witnesses a range of studies analyzing recent populist movements and their impact on international law, in particular, in the fields of trade, ${ }^{2}$ environment, ${ }^{3}$ human rights ${ }^{4}$ and migration..$^{5}$ International law is often approached in a binary/antagonistic manner, either as a tool to ban populist-driven policies or as an instrument to allow such policies to thrive. This binary style of research tends to simplify the populist movement, and miss more nuanced accounts of interaction and co-production of domestic regime (il)legitimacy and international ordering as part of a continuum that does not fit "either/or" accounts. The existing research often focuses on the United States ("U.S.") and economically stronger European countries as these countries have experienced populist

BLOOM, Peter. We live in a populist age: but who are "the people"?". The Conversation, Aug. 9, 2018. Available at: https:// theconversation.com/we-live-in-a-populist-age-but-who-are-thepeople-91793.

2 COLANTONE, Italo; STANIG, Piero. The trade origins of economic nationalism: import competition and voting behavior in western Europe. American Journal of Political Science, v. 62, n. 4, p. 936-952, 2018.

3 BEESON, Mark. Environmental populism: the politics of survival in the Anthropocene. Palgrave: MacMillan, 2019.

4 ALSTON, Philip. The populist challenge to human rights. Journal of Human Rights Practice, v. 9, n. 1, p. 1-15, 2017.

5 HAYES, Alexander Rossell; DUDEK, Carolyn Marie. How radical right-wing populism has shaped recent migration policy in Austria and Germany. Journal of Immigrant \& Refugee Studies, v. 18, n. 2, p. $133-150,2020$. movements due to increasing polarization in the past several years. ${ }^{6}$ Literature focusing on the Global South is scant. Nonetheless, as populism is essentially linked to nativism, ${ }^{7}$ jingoism, ${ }^{8}$ and authoritarianism, ${ }^{9}$ the South countries need to be investigated as well, given their close association with nationalism and localism especially when they came to participate in the rule-of-law dialogues.

This article offers some insights to the understanding of populism from three perspectives: behaviors, regimes ${ }^{10}$ and actors.

The decade since the 2008 global financial crisis has been characterized by increased populism ${ }^{11}$ and skepticism towards globalization. ${ }^{12}$ As a result, there is increased evidence to suggest an emerging new world order due to great focus of governments on national interests rather than multinational solutions.

At the national level, populism gives rise to viable political associations, parties, and interests that have largely elicited dismissive and passive aggressive responses from the established political classes. Many national economies are now framed by weaker political and regulatory institutions, resulting in nonmarket threats such as border and migration disputes, judicial arbitrariness, increased regulatory uncertainty, and rising social inequality. ${ }^{13}$ Nation states, in turning themselves to regulatory

6 NORRIS, Pippa; INGLEHART, Ronald. Cultural backlash: Trump, Brexit, and authoritarian populism. Cambridge: Cambridge University Press, 2019.

PAPPAS, Takis S. Exchange: how to tell nativists from populists. Journal of Democracy, v. 29, n. 1, p. 148-52, 2018.

8 LEMANN, Nicholas. The fate of populism in 2018. The New Yorker, Nov. 3, 2017. Available at: https://www.newyorker.com/news/ news-desk/the-fate-of-populism-in-2018.

9 CLEMENTS, Kevin P. Authoritarian populism and atavistic nationalism: $21^{\text {st }}$-century challenges to peacebuilding and development. Journal of Peacebuilding \& Development, v. 13, n. 3, p. 1-6, 2018.

10 Robert Keohane calls international institutions and organizations are "regimes", facilitating cooperation among states. KEOHANE, Robert O. After hegemony. Princeton: Princeton University Press, 1984.

11 MIAN, Atif; SUFI, Amir; TREBBI, Francesco. Resolving debt overhang: political constraints in the aftermath of financial crises. American Economic Journal: Macroeconomics, v. 6, n. 2, p. 1-28, 2014. 12 DIPPEL, Christian; GOLD, Robert; HEBLICH, Stephan. Globalization and its (dis-)content: trade shocks and voting behavior. NBER Working Paper 21812, 2015. Available at: http://www.nber. org/papers/w21812.

13 PASTOR, Lubos; VERONESI, Pietro. Inequality aversion, populism, and the backlash against globalization. NBER Working Paper 24900, 2019. Available at: http://www.nber.org/papers/w24900; HUFE, Paul; KABUR, Ravi; PEICHL, Andreas. Measuring unfair inequality: reconciling equality of opportunity and freedom from 
or police states, have developed more laws than ever on migration, tax, trade, investment, technology and intellectual property. At the international level, populist governments often take a blaming strategy ${ }^{14}$ shifting the liability of political or economic governance failure to other political association domestically ${ }^{15}$ or other states internationally. When the populist countries are unable to achieve their objectives in bilateral or multilateral negotiations, they take unilateral actions towards others.

Populism leaders also emerged in various forms across a wide range of political and geographical terrain in economically weaker regimes. Their public policy choices can be basically labeled by unilateralism, strengthened by their decisions to retreat from some common values ${ }^{16}$ or withdraw from multilateral framework and international cooperation. ${ }^{17}$ Internationally, a number of issues such as immigration, environmentalism, local protectionism and Euroscepticism have been highly politicized. Populism leads to fragmentation evidenced by the demise of the WTO, the ICSID, the World Bank, among others. The populist victories in a good number of national elections further enhanced uncertainty for multinational enterprises pondering investment, expansion opportunities, and locational choices. Arbitrary legal rulings, government instability, regulatory overhaul, lop-sided and underdeveloped consumer markets, biased or polarized media, among others, destabilize the compliance regime and increase transaction costs. These institutional uncertainties and weaknesses at the global level challenge the legitimacy of global governance system and constrain the decision-making process of multinational enterprises.

Global South is not taking a laid-back approach

poverty. CEPR Discussion Paper 12989, 2018.

14 HAMELEERS, Michael. Framing blame: toward a better understanding of the effects of populist communication on populist party preferences. Journal of Elections, Public Opinion and Parties, v. 28, n. 3, p. 380-398, 2018.

15 LISI, Marco. Populism, blame shifting and the crisis: discourse strategies in portuguese political parties. South European Society and Politics, v. 23, n. 4, p. 405-427, 2018.

16 ROTH, Kenneth. The dangerous rise of populism: global attacks on human rights values. Human Rights Watch Global Report. 2017. Available at: https://www.hrw.org/world-report/2017/country-chapters/dangerous-rise-of-populism.

17 BUMP, Philip. Where the US has considered leaving or left international agreements under Trump. The Washington Post, June 30, 2018. Available at: https://www.washingtonpost.com/news/politics/wp/2018/06/29/where-the-u-s-has-considered-leaving-orleft-international-agreements-under-trump/. in this populism movement. ${ }^{18}$ Rather, developing and emerging states are striving for a better stance in the global market. After the global financial crisis, the emergence of sovereignty wealth funds and the revival of state-owned enterprises as the key players in the global market is drawing tremendous attention and criticism in the label of state capitalism.

The article proceeds as follows. Section 2 examines the bilateral trade tension, with the focus on the U.S.'s manipulation of unilateral sanctions and one-sided negotiation strategies in a rift caused by the so-called China's failure to observe its WTO obligations, to maximize its own best interests and competitive advantages. Section 3 moves to attack intactness of existing international order, by analyzing the trend of Southern states' withdrawal from the ICSID and the investor-state dispute settlement mechanism (ISDS). Then in Section 4 we approach the populist issue from a country-specific angle, by investigating how the revival of state capitalism, through its unilateral approaches to advancing national interests, has changed and will further challenge the existing international infrastructure order.

\section{Populism and Engagement of Unilateralism}

After the global financial crisis, populist politics have been on the rise. As an ideology, populism segregates between the "pure people" (who are left behind from the globalization and technological advancement) and the "corrupt elite" (represented by the government or political establishment), and disrupts the political sphere across the world. In the legal sphere, the people are more concerned about immigration and civil rights than they do about redistribution of wealth in the society to correct economic inequality. They are more dissatisfied with "others" than "us" and see "others" as the source of economic inequality and social problems. This offers a potential explanation for a divide between the "first" and the rest, shifting the blame to other countries which stole the jobs and technologies, swallowed their manufacturing entities, just mention a few. This change is ha-

\footnotetext{
18 BARDHAN, Pranab. Populism in less developed countries is somewhat different. 3 Quarks Daily, August 6, 2018. Available at: https://www.3quarksdaily.com/3quarksdaily/2018/08/populismin-less-developed-countries-is-somewhat-different.html.
} 
ving profound effects on the global governance system built upon liberal democracy. The populist governments take a much more aggressive approach to international trade imbalances or other "governance deficits". Instead of relying on bilateral negotiations and multilateral structures such as the WTO, the populist approach is to stick to unilateral sanctions, pressing the counterparties to accept and adopt the pre-set agenda and standards.

In the United States, the election of Donald Trump as the President has been seen as a symbolic moment that voters are moving towards populist leaders. The emerging "Trump philosophy" has been said to be an entire departure from multilateralist cooperation ideologies. As Professor Harold Koh observed, Trump's instincts seem to disengage from multilateralism through unilateralism, or, as he calls it, "America First". ${ }^{19}$ Under this worldview, the United States should only act based its perceived national interests other than international rules. This is in contrary to such views that the United States was founded on universal rights, and is at odds with foundational principles of modern international law. ${ }^{20}$ To Trump supporters, by resorting to unilateralism, states can and do act unilaterally to resolve, or at least mitigate, the failing effect of multilateralism.

One area of Trump's foreign policy-making involves a series of withdrawals from international agreements or international institutions the United States was part of as indicated in Table 1 below. These withdrawals not only damages the health of multilateral institutions but also demonstrates a backdrop of rising populist, isolationist and anti-global political sentiment. ${ }^{21}$

Table 1 - US's Recent Withdrawals and/or Renegotiations of Multiple Arrangements

\footnotetext{
$19 \mathrm{KOH}$, Harold Hongju. The Trump administration and international law. Washburn Law Journal, v. 56, n. 413, p. 420, 2017.

$20 \mathrm{KOH}$, Harold Hongju. The Trump administration and international law. Washburn Law Journal, v. 56, n. 413, p. 420, 2017.

21 BROLMANN, Catherine M.; COLLINS, Richard; EL DROUBI, Sufyan; WESSEL, Ramses A. Exiting international organizations: a brief introduction. International Organizations Law Review, v. 15, n. 2, p. 243-263, 2018.
}

\begin{tabular}{|c|c|c|}
\hline $\mathrm{N}^{\mathbf{o}}$ & $\begin{array}{l}\text { International Agreement/ } \\
\text { Institution }\end{array}$ & $\begin{array}{l}\text { Trump administration's } \\
\text { action }\end{array}$ \\
\hline 1. & $\begin{array}{l}\text { Intermediate-Range Nuclear } \\
\text { Forces Treaty } 1987\end{array}$ & Pulled out \\
\hline 2. & Paris Agreement 2015 & Pulled out \\
\hline 3. & $\begin{array}{l}\text { Trans-Pacific Partnership } \\
2016\end{array}$ & Pulled out \\
\hline 4. & $\begin{array}{l}\text { South Korean Trade Deal } \\
\text { (KORUS) } 2012\end{array}$ & Renegotiated $^{22}$ \\
\hline 5. & NAFTA 1994 & $\begin{array}{l}\text { Signed the US-Mexico- } \\
\text { Canada Agreement to } \\
\text { replace it }\end{array}$ \\
\hline 6. & Groups of Seven 1975, 2014 & Wants to include Russia \\
\hline 7. & Singapore Agreement 2018 & Signed \\
\hline 8. & $\begin{array}{l}\text { UN Human Rights Council } \\
1946\end{array}$ & Pulled out \\
\hline 9. & $\begin{array}{l}\text { UN Educational Scientific } \\
\text { and Cultural Organization } \\
1945\end{array}$ & Pulled out \\
\hline 10. & $\begin{array}{l}\text { Iran Nuclear Deal } \\
\text { (Joint Comprehensive Plan } \\
\text { of Action 2015) }\end{array}$ & Pulled out \\
\hline 11. & $\begin{array}{l}\text { Treaty of Amity } 1955 \text { with } \\
\text { Iran }^{23}\end{array}$ & Pulled out \\
\hline 12. & $\begin{array}{l}\text { Optional Protocol under the } \\
1961 \text { Vienna Convention of } \\
\text { Diplomatic Relations }{ }^{24}\end{array}$ & Pulled out \\
\hline 13. & $\begin{array}{l}\text { UN Relief and Works } \\
\text { Agency }\end{array}$ & $\begin{array}{l}\text { Ended its decades of } \\
\text { funding }\end{array}$ \\
\hline 14. & NATO & $\begin{array}{l}\text { Threatened to "go its own } \\
\text { way" if other members did } \\
\text { not spend more on defense }\end{array}$ \\
\hline 15. & WTO 1995 & $\begin{array}{l}\text { Threatened to pull out and } \\
\text { blocked the appointment of } \\
\text { new judges to the appellate } \\
\text { body }\end{array}$ \\
\hline
\end{tabular}

Another area involves various unilateral sanctions against multiple national sanctions including Iran, Rus-

22 Due to President Trump's displeasure with the Korea-US Free Trade Agreement (often referred to as KORUS), the US and South Korea renegotiated the agreement, which became Trump's first trade deal. KORUS 2.0 is a tweak of the original KORUS but contains some major changes demanded by the US including steel export restrictions, a larger quota for U.S. cars exported to Korea that meet U.S. emissions and safety standards instead of Korea's idiosyncratic rules, an extension of the duration of the U.S. 25\% tariffs on imported pickup trucks, changes to rules on Korean medicine pricing, and new procedures for Korean customs inspections. LESTER, Simon; MANAK, Inu; KIM, Kyounghwa. Trump's first trade deal: the slightly revised Korea-US free yrade agreement. CATO Institute, June 13, 2019. Available at: https://www.cato.org/publications/ free-trade-bulletin/trumps-first-trade-deal-slightly-revised-koreaus-free-trade.

23

24 RAMPTON, Roberta. US withdraws from international accords, says UN World Court 'politicized'. Reuters, October 4, 2018. Available at: https://www.reuters.com/article/us-usa-diplomacytreaty/us-reviewing-agreements-that-expose-it-to-world-court-bolton-idUSKCN1MD2CP. 
sia, North Korea, Venezuela and China, to achieve U.S. specific goals. In January 2017, Trump signed executive order: the Travel Ban for 90 days blocked entry into the United States by citizens of seven predominately Muslim countries. In September of the same year, the Ban was adjusted to add North Korea and Venezuela, and barred individuals with valid visas and green cards from those countries from re-entering the United States. ${ }^{25}$ During the recently concluded U.S.-China Trade War, Trump ordered a Special 301 investigation of China in 2018 and put China on the Special 301 "Priority Watch List". ${ }^{26}$ As a broad regulatory measure, sanctions under Section 301 can include reduction in aids, the suspension of trade concessions, or the creation of some import restrictions. ${ }^{27}$ Section 301 also permits the United States to reach behaviors of Chinese enterprises that have little to do with the state's alleged violative practices. ${ }^{28}$ At the same time, Section 301 also gives the government broad power to sanction foreign corporations. The US Department of Commerce in May 2019 issued a Final Rule adding Huawei Technologies Co. Ltd. (Huawei) and its 68 non-US affiliate ${ }^{29}$ to the Bureau of Industry and Security (BIS) "Entity List". ${ }^{30}$ The Entity List, maintained as Supplement No. 4 to Part 744 of the Export Administration Regulation ("EAR"), identifies legal and natural persons believed to be involved, or to pose a significant risk of being or becoming involved, in activities contrary to the national security or foreign policy interests of the United States. ${ }^{31}$ This cut off Huawei

25 Protecting the Nation from Foreign Terrorist Entry into the United States, 82 Fed. Reg. 8977 (Jan. 27, 2017).

26 RAMPTON, Roberta. US withdraws from international accords, says UN World Court 'politicized'. Reuters, October 4, 2018. Available at: https://www.reuters.com/article/us-usa-diplomacytreaty/us-reviewing-agreements-that-expose-it-to-world-court-bolton-idUSKCN1MD2CP.

27 See BELLO, Judith H.; HOLMER, Alan F. Special 301: its requirements, implementation, and significance. Fordham International Law Journal, v. 13, n. 259, 1990.

28 See BELLO, Judith H.; HOLMER, Alan F. Special 301: its requirements, implementation, and significance. Fordham International Law Journal, v. 13, n. 259, 1990.

29 These non-US affiliates are located in 26 countries.

30 The restrictions were posted by the Department of Commerce on the Federal Register Notice on May 16, 2019. All items in the United States are subject to the jurisdiction of the Department of Commerce and EAR, a list of organizations as identified by BIS as engaging activities that could be contrary to the national security or foreign policy interests of the United States are included in the BIS list, and United States enterprises are banned from exporting to organizations on the Entity List.

31 BIS cited the 13 court indictment against Huawei accusing Huawei of willfully conducting and concealing millions of dollars' worth from the supply chain and Huawei would be unable to acquire US-origin hardware, software and technology directly or indirectly. ${ }^{32}$ Further, the US government, in its zero-sum thinking of a "race to $5 G$ ", ${ }^{33}$ has been in an intensive outreach campaign trying hard to persuade its allies such as the EU, Australia and Japan not to use Huawei's equipment for their own $5 \mathrm{G}$ programs though the allies largely resisted such proactive efforts. ${ }^{34}$

As the dominant financial superpower of the world, following September $11^{\text {th }}$, the United States has made concerted efforts to choke off funding for terrorist organizations like al Qaeda and ISIS. Similarly, it has used denial of access to the global financing system and economic sanctions to aggression by North Korea, Syria, Iran and Russia. These series of economic and financial sanctions including asset freezes, import tariffs, trade barriers, travel restrictions, import/export ban, and embargos, are designed to cause financial damage and distress to the sanctioned states, and are largely effective. ${ }^{35}$ The secondary sanction, which refers to regulatory efforts preventing foreign corporations from doing business with a sanctioned state, ${ }^{36}$ like the U.S. request for the extradition Huawei Technology's Chief Financial Officer from Canada during the U.S.-China Trade War, based on Huawei's engagement in trade with Iran, has been attacked by many for the weakness or even lack of

of transactions in violation of US economic transactions against Iran. The indictment accuses certain non-US Huawei affiliates of having participated in the alleged criminal conduct.

32 The restrictions affect US subsidiaries of foreign companies which are US persons and US companies' business with any foreign companies that have contracts with Huawei involving information or communications technology or services. The US-origin items can be located in the US or other places in the world, or exported from the US, or any foreign-made item with more than 25\% US-origin content or 10\% US-origin content for countries subject to US sanctions, or any foreign-made item that is the direct product of certain controlled US-origin software, technology, or major plant or equipment located abroad.

33 AMERICA v. China Huawei and 5Geopolitics. The Economist, Apr. 11-17, 2020. at 10.

34 WOO, Stu; O'KEEFFE, Kate. Washington asks allies to drop Huawei. The Wall Street Journal, Nov. 23, 2018. Available at: https://www.wsj.com/articles/washington-asks-allies-to-drop-huawei-1542965105. Access: Mar. 31, 2020.

35 See GURULE, Jimmy. The demise of the U.N. economic sanctions: regime to deprive terrorists of funding. Case W. Res. J. Int'L, v. 41, n. 19, p. 20-28, 2009.

36 CLARK, Harry L. Dealing with U.S. extraterritorial sanctions with foreign countermeasures. U. PA. J. International Economics and Law, v. 20, n. 61, p. 63-64, 1999. (discussing U.S. efforts to induce foreign corporation to abide by U.S. sanctions against third countries, such as Cuba or Iran). 
legal foundation. ${ }^{37}$

International legal scholars have been calling for a further differentiation between legal and illegal unilateral sanctions. Like Devika Howell argues, due to international order's consent-based nature, sanctions should not cross the line from inducing states to do something it is not bound to do under international law. ${ }^{38}$ Customary international law also provides that a state has violated an international obligation to another state or an obligation to all states as it is subject to certain "peaceful retaliatory" measures that would "otherwise be illegal". ${ }^{39}$ Therefore, unilateral sanctions can become problematic when they are associated with one community imposing its values on another, where that other community has not consented to the imposition of such values. ${ }^{40}$ In many circumstances, the type of wrong being sanctioned is linked to an existing international obligation. Under such circumstances, it is more likely for the being sanctioned country to remedy their wrong by making it in line with its prior international commitments. If the type of wrong sanctioned is connected only to a bilateral norm, the state being sanctioned is less likely to change its behavior unless doing so is in its own interest after a cost-benefit analysis. ${ }^{41}$ However, within the United States, there has been such view that "within the broad limit of international law, every country must retain the authority to impose sanctions to protect its sovereign security interests." ${ }^{\prime 2}$ This argument is further bolstered by the more widely agreed statement that international institutions like the United Nations are particularly hard to build up necessary measures to support effective sanctions given the rudimentary inter-

\footnotetext{
37 MALAWER, Stuart S. Pending section 232 litigation and broader trade trends: will the US courts restrict presidential authority from relying upon national security?. China \& WTO Review, v. 1, n. 183, p. 185, 2019.

38 TZANAKOPOULOS, Antonios. The right to be free from economic coercion. Cambridge International Law Journal, v. 4, p. 616-617, 2015.

39 CLEVELAND, Sarah. Norm internalization and economic sanctions. 55.

40 SANDS, Phillippe. Unilateralism, values and international law. EJIL, v. 11, p. 291-293, 2000.

41 ACEVES, Williams J. The economic analysis of international law: transaction cost economics and the concept of state practice. University of Pennsylvania Journal of International Economic Law, v. 17, n. 4, p. 996-1068, 1996; TRACHTMAN, Joel P. Trade and ... problems: cost-benefit analysis and subsidiarity. European Journal of International Law, v. 9, p. 32-85, 1998. (arguing the cost-benefit analysis is not applied, and the utility of trade-off devices instead).

42 COHEN, David; GOLDMAN, Zachary. Like it or not, unilateral sanctions are here to stay. ASIL Unbound, 2019.
}

national law enforcement mechanism. ${ }^{43}$

Populism aims to promote national interests and to detach from globalization, multilateralism, and free movement of goods, services, capital and labour. It threatens global commitments on free trade, climate change, energy sustainability, among others, and challenges the so-called liberal democratic conceptions relating to the rule of law and international cooperation. The recurrent populist "blame game" or hostility towards foreign states, international organizations and international law overshadows legitimate concerns as regards other states and global governance as a whole. While the blame-game occurs in the global scale, the regional idiosyncrasies and the country study may make greater sense.

Many of the tactics that populist leaders use have gained themselves stronger voter support, but weaken international legal order, democratic institutions and executive power. Unlike his predecessor, a populist leader like Trump does not seem to believe in any form of universal rights. Good at fueling polarization of the society by commitment to name calling on social media, disinformation and "fake news", these leaders of Western democracies show little differences with their counterparts in totalitarian or authoritarian regimes. As societies grow more polarized, people become willing to tolerate abuses of power and sacrifice democratic principles, which together increases the risk of broken down of any form of existing international order.

\section{Populism and Disengagement of International Mechanisms}

The current global economic governance was essentially shaped by the states' surrender of sovereignty to international institutions and global governance system after the World War II with the common ground of achieving peace, stability and prosperity.

Contemporary populist regimes are tainted by a vulgarized version of neoconservative ideology, encompassing anti-environmentalism, ethno-nationalism and primitive sovereigntism. With the re-emergence of populism, popular sovereignty has resurfaced as a political category, calling into question understandings of globa-

COHEN, David; GOLDMAN, Zachary. Like it or not, unilateral sanctions are bere to stay. ASIL Unbound, 2019. 
lization and international cooperation.

One of the targets of populist ideology and populist political action has been the judicialization of international economic law in globalization, accusing of semi-judicial elitism in investor-state dispute settlement mechanism criticizing the elite arbitration circle and its detachment from the host states, their people and the democratic systems. The critique concerns the ISDS's tendency towards creating government des judges and the anti-demoliberal status quo ante.

The ICSID arbitration regime based on the ICSID Convention is a vital component for maintaining the operation of the modern international investment law regime. The mode of resolving investment disputes by urging the host state to transfer and delegate part of its judicial sovereignty is the central aspect and powerful illustration of the "leaving" of the states in the field of international investment law.

The legal norms in favor of foreign investment protection advanced by the ICSID encountered some defects resulting from a series of controversial cases. These defects showcase how the regulatory space of states were overlooked, affected and even diminished by arbitral practices in the ICSID proceedings, and more importantly, how democratic or public choices available to the host state government were compromised by these arbitration cases.

The application of the host state's law in ICSID arbitration depends entirely on the interpretation of the arbitration tribunals. More often, arbitration tribunals prefer to apply an expansive approach to interpreting vaguely defined substantive terms in the BITs. By doing so, the host state's sovereign acts are reviewed by a tribunal against standards that do not have definite content. ${ }^{44}$ The ICSID arbitration tribunal has also defined its position of restricting the application of the host state's law in real practice.

The main methods adopted are as follows. First, international law is used to exclude the application of the host state's domestic law. In the case of Wena Hotels v. Egypt, the arbitration tribunal once pointed out that the ICSID Convention does not limit the scope of application of the host state's law and international law (including BITs) so that the arbitration tribunal is

44 SORNARAJAH, M. The international law on foreign investment. 2. ed. Cambridge: Cambridge University Press, 2004. p. 233. entitled to decide on the specific applicable law. ${ }^{45}$ In the case of ADC Affiliate v. Hungary, facing the BIT's explicit agreement to apply the host state's law to the calculation of compensation for expropriation, the arbitration tribunal directly excluded the application of the host state's law to other disputed matters, emphasizing its position that international law shall be applied preferentially except for special agreements in the BIT. ${ }^{46}$ Second, the influence of the host state's law is diluted by its combination with international law. In the case of Antoine v. Burundi, the arbitration tribunal recognized that excessive restrictions on the host state's law will lead to an imbalance of interests in the investment arbitration regime. ${ }^{47}$ Therefore, when settling disputes, the host state's law and international law are often combined to be used to deal with the cases. In this process, in applying the host state's law at the parties' choice, the arbitration tribunal emphasized the supplementary, corrective and even restrictive function of international law. ${ }^{48}$ In other words, it is a tendentious application and a pragmatic way of dissolving the host state's law by international law in an attempt to prioritize international law in ICSID arbitration over the host state's domestic law. This tendency to exclude and restrict the application of the host state's law has occurred frequently in the ICSID arbitration practices in recent years. In the case of Kim and others $v$. Uzbekistan, when the host state interpreted the BIT in accordance with the Vienna Convention on the Law of Treaties to prove that when investors violate the laws of that state and raised objections to jurisdiction, the arbitration tribunal, while demonstrating the applicability of the Vienna Convention on the Law of Treaties, ${ }^{49}$ still rejected the host state's

45 Wena Hotels Ltd. v. Arab Republic of Egypt, ICSID Case No. ARB/98/4, Ad Hoc Committee Decision on Application for Annulment, 2002, ICSID Report, v. 6, p. 933, 2004.

46 ADC Affiliate Limited and ADC \& ADMC Management Limited v. The Republic of Hungary, ICSID Case No.ARB/03/16, Award, p. 288-293, 2006.

47 See Antoine Goetz and others v. Republic of Burundi, ICSID Case No. ARB/95/3, Award, p. 98, 1999.

48 See HONGRUI, Chen. The application of host state's law in international investment arbitration: the acceptability of article 30 of US model BIT. Journal of International Economic Law, Chen An ed., University Press, p. 162-167, 2010. (Chen Hongrui: Lun Dong Dao Guo Fa Lv Zai Guo Ji Tou Zi Zhong Cai Zhong De Shi YongJian Ping 2004 Nian Mei Guo BIT Fan Ben Di 30 Tiao De Ke Jie Shou Xing, Chen An Zhu Bian: Guo Ji Jing Ji Fa Xue Kan, v. 17, n. 4, Beijing: Bei Jing Da Xue Chu Ban She, p. 162-167, 2010.)

49 The Vienna Convention on the Law of Treaties, adopted and opened for signature on 23 May 1969, entered into force 27 January 1980 (1155 United Nations Treaty Series 331) was acceded to by 
defense on the vague ground that investors had conducted investment activities in accordance with the host state's law and did not seriously damage the interests of the host state, deliberately avoiding the application of the host state's law. ${ }^{50}$ Although Philippe Sands, the arbitrator in this case, held in a dissenting opinion that the host state's law should be considered and applied in combination with relevant international laws ${ }^{51}$ based on the opinions of the arbitration tribunal in the case of Urbaser v. Argentina, ${ }^{52}$ this view was not supported or adopted by other arbitrators finally. In the case of Bear Creek Mining v. Peru, the host state proposed that the host state's local law should be treated differently from international law. However, the arbitration tribunal rejected this view. ${ }^{53}$ Therefore, in ICSID arbitration, even if the ICSID Convention and BITs both stipulate that the host state's law can be applied, the arbitration tribunal often evades the application of the host state's law. Even if the host state's law has to be applied, other methods have often been employed to control the influence of the host state's law to a minimum level.

Apart from the application of the host state's law in ICSID arbitration, relevant cases also show an ICSID arbitration tribunal's inclination towards investors in the interpretation and application of umbrella clauses and most-favored-nation treatment clauses. ${ }^{54}$ Investment arbitration tribunals' expansive but conflicting interpretations have technically turned substantive standards in the BITs such as the fair and equitable treatment standard to grey ones which made the sovereignty of host states more vulnerable while potentially creating a safer investment environment for foreign investors. The discrepancies between varying interpretative approaches have turned into sheer chaos, ${ }^{55}$ which has been labe-

Kazakhstan on 5 January 1994 and by Uzbekistan on 12 July 1995.

50 Pavel Borissov, Aibar Burkitbayev, Almas Chukin and others v. Republic of Uzekekistan, ICSID Case No. ARB/13/6, Decision on Jurisdiction, para. 413, 541, 2017.

51 See Pavel Borissov, Aibar Burkitbayev, Almas Chukin and others v. Republic of Uzbekistan, ICSID Case No.ARB/13/6, Partial Dissenting Opinion Professor Philippe Sands QC, para. 102017.

52 See Urbaser S.A. and Consorcio de Aguas Bilbao Biqkaia, Bilbao Biskaia Ur Partuergoa v. The Argentine Republic, ICSID Case No. ARB/07/26, Award, para. 1199, 2016.

53 See Bear Creek Mining Corporation v. Republic of Peru, ICSID Case No. ARB/14/21, Award, p. 267-269, 2017.

54 See EGLI, Gabriel. Don't get bit: addressing ICSID's inconsistent application of most-favored-nation clauses to dispute resolution provisions. Pepperdine Law Review, v. 34, p. 1045-1084, 2007.

55 MANCIAUX, Sébastien. The notion of investment: new controversies. Journal World Investment and Trade, v. 9, p. 443-444, 2008. led as a legitimacy crisis of the ISDS system, calling for taking an urgent and effective measure to end the possible manipulation of these substantive standards offering stability and predictability conducive to the host state's regulation over health, environment and other economic, regulatory and social issues. ${ }^{56}$

As a result of the vagueness of substantive terms in a large number of BITs, the inconsistent interpretative techniques applied by a large number of arbitration tribunals probably with the pre-set objective of offering better rights protection to foreign investors as well as the lack of independence of ISDS owing to a close-knit community of party-appointed international arbitrators ${ }^{57}$ the ISDS system left varying negative impressions to the users and commentators. Some cases may have indicated a tendency that investors from wealthy states were equipped with more power over the governments of less wealthy host states while other cases may have justified the existence and utility of ISDS as a tool of protecting foreign investors from opportunistic actions like expropriations in host states without strong rule of law and legal institutions. Consequently, both accusations may be in existence simultaneously weak or poor host states are fighting large multinational companies while private entities are fighting arbitrary actions taken by developing states. Increasing public disapproval has shaken the public confidence over the ISDS and caused public outcry.

It is precisely the excessive investor protection in ICSID arbitration that causes more states' dissatisfaction with this regime. In light of relevant statistics, over the past 30 years, Latin American states, represented by Argentina and Bolivia, have been among the top respondent states in ICSID arbitration cases. The large-amount of compensation arising from investment arbitration cases became a vital factor affecting these countries' economic development. Since 2007, Bolivia, Ecuador, Venezuela, and other states have announced their decisions to withdraw from the ICSID Convention. Argentina was to reconsider its participation in the regime because more than 60 arbitration cases have dragged down its economic development. ${ }^{58}$ 56 ACHAVAL, Clara Picasso. Tipping the balance towards inves-
tors. Journal World Investment and Trade, v. 9, p. 147-162, 2008.
$57 \quad$ KARAMANIAN, Susan. International decision, Compania de
Aguas del Aconquija S.A. \& Vivendi Universal S.A. v Argentine Re-
public. American Journal of International Law, v. 105, p. 553-555, 2011.
$58 \quad$ See GOODMAN, Charity L. Uncharted waters: financial crisis 
There has been a domino effect in Latin America. After having entered 23 BITs, Bolivia denounced the ICSID Convention in 2007. After the new Constitution of Bolivia was enacted, the government announced its plan to denounce and renegotiate the existing BITs as they were deemed to be contrary to the new Constitution. Ecuador's denunciation was notified in July 2009 and came into effect in January 2010..$^{9}$

Venezuela announced its withdrawal in late January 2012 which became effective in July 2012. The Foreign Ministry's 2012 press-release points out that the country acceded to the ICSID Convention in 1993 by "a decision of a provisional and weak government, devoid of popular legitimacy, and under the pressure of transnational economic sectors involved in the dismantling of Venezuela's national sovereignty." 60

The decision to withdraw from the ICSID Convention matches the then Chavez government's economic program seeking to re-establish the role of the state in the economy and re-control the so-called strategic sectors including petroleum, steel, agribusiness, construction, telecommunications and banking which were farmed out to foreign investors in the 1990s. Although the claw-back policies entail foreign investors' grievances against the government and consequently the investor-state investment disputes which were submitted to the ICSID, they allow Venezuela to walk out of its commitment under the ICSID Convention to pay "full" compensation to grieved foreign investors, which makes any major social or economic program impossible. ${ }^{61}$ Venezuela is the second only to Argentina and has 20 cases pending against it at the ICSID, facing the prospect of having to pay billions to successful claimants. ${ }^{62}$ These filed cases are not affected by Venezuela's denunciation

and enforcement of ICSID Awards in Argentina. University of Pennsylvania Journal of International Economic Law, v. 28, p. 449-483, 2007.

59 FIEZZONI, Silvia Karina. The challenge of UNASUR member countries to replace ICSID arbitration. Beijing Law Review, v. 2, p. 134-136, 2011.

60 Gobierno Bolivariano denuncia convenio con Ciadi. 25 Jan. 2012. Available at: http://www.cadtm.org/Gobierno-Bolivariano-denuncia. Access: Feb. 12, 2019.

${ }_{61}$ BROWNLIE, Ian. Principles of public international law. 6. ed. Oxford: Clarendon Press, 2003. p. 513; PAASIVIRTA, E. Participation of states in international contracts and arbitral settlement of disputes. Helsinki: Finnish Lawyers’ Publishing Company, 1990. p. 265.

62 This number includes 16 ICSID arbitrations proper and 4 arbitrations under the ICSID Additional Facility Rules. See http://icsid. worldbank.org. According to UNCTAD's information, there are no (publicly known) IIA-based claims pending against Venezuela in other international fora. of the ICSID Convention. ${ }^{63}$ Venezuela's discontent with the ICSID has universal significance in light of the general trend towards increasing state intervention in the economy ${ }^{64}$ especially in these countries with a regime change. ${ }^{65}$

The increasing importance of Latin American states before ICSID proceedings, and, more importantly, the unfavorable decisions rendered towards them, probably justifies the denunciation of the ICSID Convention by these countries and explains the regional discussions to have an alternative regional framework to deal with the ISDS system under the auspices of the World Bank. ${ }^{66}$ As of May 2013, Latin American countries were parties in 81 out of 262 cases concluded (approximately 31\%). Of the 167 cases still pending, 73 of them were against Latin American countries (approximately 44\%). ${ }^{67}$ Argentina alone had 25 cases before ICSID of the 167 pending cases passed a draft bill dated March 21, 2012, and indicated its plan to exit. ${ }^{68}$ Since 2001 when the Argentine economy collapsed, Argentina has faced 43 claims that amount to approximately US\$65 billion in damages. The ICSID has awarded claimants over US $\$ 400$

63 Theoretically, disgruntled foreign investors will be able to initiate new cases during the six months between the notice of denunciation and the date when it becomes effective on July 25, 2012.

64 See UNCTAD. World Investment Report 2011. p. 9 et seq.

65 EL-KADY, H. Egypt's bilateral investment treaties: a straitjacket in a new era of foreign investment re-regulations?. Dec. 12, 2011. Available at: https://www.transnational-dispute-management.com/Article asp?key=1826\#citation. Access: Jan. 29, 2019.

66 In the first 100 cases of ICSID, Latin American countries were concerned by 25 cases ( 8 cases for Argentina, 7 for Mexico, 3 in Venezuela and other countries with one). But in recent years, "ICSID has witnessed a dramatic increase in the number of arbitrations where Latin American countries are respondents". GOMEZ, Katia Fach. Latin America and ICSID: David versus Goliath. Law and Business Review of the Americas, v. 195, p. 195, 2011. For a total of 262 cases (indicated at ICSID website), Latin American countries are concerned by 81 cases (let say 30,9\% of concluded cases): Argentina 25 cases, Mexico 13, Ecuador 10, Venezuela 11, Peru 6, Costa Rica 5, Bolivia, Chile and Honduras with 2 cases each, and El Salvador, Guatemala, Panama and Paraguay with one case each. There are 167 pending cases as of May 30, 2013, and the number of cases concerning Latin American Sates is 73, (let say $43.7 \%$ of the total number of pending cases): Argentina with 25 cases, Venezuela with 25, Peru 6, Ecuador and Guatemala with 3 each, Bolivia, Costa Rica and El Salvador and Paraguay with 2, Chile, Honduras, and Uruguay with one each.

67 BEOGLIN, Nicolas. ICSID and Latin America: criticisms, withdrawals and regional alternatives. Comm for the Abolition of Third World Debt, Jul. 4, 2013.

68 Bill of Argentina Congress dates April 21, 2012. Text of the draft of that bill. Available at: http://www1.hcdn.gov.ar/proyxml/ expediente.asp? fundamentos $=$ si\&numexp $=1311-\mathrm{D}-2012$. Access: Feb. 29, 2019. 
million. ${ }^{69}$ Many states of the American hemisphere remain distant from the ICSID - Canada, Cuba, Mexico and Dominican Republic have not ratified the ICSID Convention. Costa Rica signed the ICSID Convention in 1982 but ratified it 12 years later.

Withdrawals from ICSID by Bolivia, Ecuador, Venezuela and Argentina, and their termination of BITs ${ }^{70}$ are not only a radical expression of these countries' dissatisfaction with the ICSID Convention-centered regime but also a dramatic portrayal of a broader trend to revisit key aspects of international investment law. The exit from the ICSID Convention and the global forum for the settlement of investment disputes signals these countries' loss of faith in the ISDS system. Although the withdrawal from the ICSID Convention does not entirely block the future international investment arbitration against these countries, denouncing the ICSID Convention does send a political message to show their refusal for future cooperation in the ICSID-centered regime, and more realistically, the lack of likelihood of the collection of damages to be ordered by ICSID tribunals against these countries.

Some scholars therefore pointed out that the Calvo Doctrine, which was once popular in Latin American states, has not died out and is possible to revive and resist in a mildly radical way. ${ }^{71}$ In this sense, the Calvo Doctrine still has value in contemporary international law even though the ICSID is said to be a superior solution to the Calvo Doctrine. ${ }^{72}$ While the ICSID in its operation indicated its mechanical or even institutional defects as an arbitration machinery and an instrument of international public policy, ${ }^{73}$ the Calvo Doctrine has emerged as a vital institutional source and theoretical basis for the "return" of developing states in the field of international investment.

Apart from the revival of the Calvo Doctrine and the withdrawal of many Latin American states from the ICSID regime, emerging economies as non-parties to

\footnotetext{
69 Come and Get Me, Economist, Feb. 18, 2012.

70 In 2008, Ecuador terminated nine BITs - with Cuba, the Dominican Republic, El Salvador, Guatemala, Honduras, Nicaragua, Paraguay, Romania and Uruguay.

${ }^{71}$ SHAN, Wenhua. Is Calvo dead?. American Journal of Comparative Law, v. 55, p. 123-163, 2007.

72 See SHIHATA, Ibrahim F. I. Towards a greater depoliticization of investment disputes: the roles of ICSID and MIGA. ICSID Review-Foreign Investment Law Journal, v. 1, n. 1, p. 24-25, 1986.

73 ICSID, Annual Report (1984) 5.
}

ICSID such as India, Brazil and South Africa, ${ }^{74}$ which have become increasingly crucial in the field of international investment in recent years, ${ }^{75}$ also restrict or even exclude the use of the ISDS regime by updating their model BITs and amending their domestic laws. The decline or rise of the Calvo Doctrine suggests the leaving or return of the state when it comes to settling its disputes with foreign investors. The changing role of the Calvo Doctrine indicates the uncertainty of its application which is likely related to the host state's view over sovereignty. Nevertheless, the principle of diplomatic protection remains part of the realities of international life. $^{76}$

For example, India's model BIT published in 2016 contains full restrictions on the ISDS mechanism. On the one hand, the model BIT highly emphasizes the local remedies such as administrative and judicial tribunals foreign investors have to rely on in resolving investment disputes with the Indian government after their rights are damaged. ${ }^{77}$ Meanwhile, India believes that the international arbitration tribunal has no right to review the judicial decisions of sovereign states, thus denying international agencies right to review the decisions of their own courts. ${ }^{78}$ Although the model BIT allows ICSID to intervene in disputes "on the premise that both parties are members of ICSID", ${ }^{79}$ the fact that India is not a member of ICSID and has no intention to join the ICSID in the years to come makes this provision meaningless.

For another example, Brazil signed a number of BITs as early as the 1990s. However, its congress did not approve these BITs in order to safeguard its right

74 By the end of January 2019, India, Brazil and South Africa had not joined ICSID. See ICSID, Available at: https://icsid.worldbank. org/en/Pages/about/Member-States.aspx. Access: Jan. 31, 2019.

75 According to World Investment Report 2018, India and Brazil have long been at the forefront of capital outflows and inflows in the world, and South Africa, as a regional investment power, has always been affecting Africa's investment outflows and inflows. See UNCTAD. World Investment Report 2018. Jun. 6, 2018. p. 4-6. Available at: https://unctad.org/en/PublicationsLibrary/wir2018_en.pdf. Access: Nov. 12, 2018.

${ }^{76}$ SHIHATA, Ibrahim F. I. Towards a greater depoliticization of investment disputes: the roles of ICSID and MIGA. ICSID ReviewForeign Investment Law Journal, v. 1, n. 1, p. 24-25, 1986.

772016 Model Text for the Indian Bilateral Investment Treaty, Articles 15.1, 15.2, 15.4, 15.5.

782016 Model Text for the Indian Bilateral Investment Treaty, at Article 13.5 .

792016 Model Text for the Indian Bilateral Investment Treaty, at Article 16.1. 
to regulate foreign capital. Brazil showed no interest in ratifying the ICSID or any BIT despite having signed some BITs and even though Brazil named the ICSID Secretary-General the "appointing authority" of arbitrators in some guarantee agreements executed by Brazil in favor of foreign lenders to Brazilian public entities. ${ }^{80}$ Since the new century, Brazil has also been having a Cooperation and Investment Facilitation Agreements (CIFA) regime for its own interests in the ICSID regime, continuing its consistent position of safeguarding its right to regulate foreign capital and restricting foreign investors' right to sue. Therefore, some scholars believe that Brazil's investment dispute settlement mechanism tends to return to the international customary law of diplomatic protection. ${ }^{81}$ Take one example. The Bilateral Investment Agreement between India and Brazil does not use investor-state arbitration but requires an ombudsman to conduct state-to-state arbitration. ${ }^{82}$

In the meantime, South Africa has also conducted in recent years a large number of reviews over those BITs signed in the last century and found that quite a number of treaties are inconsistent with its own investment policies and constitution. ${ }^{83}$ Therefore, after 2010, South Africa terminated BITs with Germany, Switzerland, the Netherlands and other states respectively, and explicitly excluded ISDS in the Investment Protection Act promulgated in $2015,{ }^{84}$ further strengthening its right to regulate foreign capital, in a bid to protect South Africa from the legal risks of being sued by foreign investors for investment disputes.

South Africa has decided to modernize its investment protection regime in a manner that balances strong protection for investors with Constitutional requirements to safeguard the public interest and promote sustainable development and inclusive growth. This has involved developing a new investment bill that would strengthen

80 DELAUME, Feorges R. ICSID and the Banker. International Financial Law Review, v. 2, n. 9, p. 13, 1983.

81 ROLLAND, Sonia E. The return of state remedies in investorstate dispute settlement: trends in developing countries. Loyola University Chicago Law Journal, v. 49, n. 387, p. 395-399, 2017.

82 See BHAT, Rohit. Will India do away with investor state arbitration? Aug. 23, 2017. Available at: http:/ / arbitrationblog.kluwerarbitration. com/2017/08/23/will-india-away-investor-state-arbitration/. Access: Jan. 30, 2019.

83 See LANG, Jonathan; GILFILLAN, Bowman. Bilateral investment treaties: a shield or a sword?. Nov. 8, 2013. p. 2-3. Available at: http:// www.bowmanslaw.com/wp-content/uploads/2016/09/PPI-article_mailshot_08112013_1038389_1-1.pdf. Access: Jan. 9, 2019.

84 Protection of Investment Act (Act No. 22/2015) (S. Aft.). and clarify protection provided to all investors in South Africa as well as terminating BITs that pose unacceptable risks to democratic policy making in South Africa, without delivering any discernible economic benefit.

The South Africa government in 2012 decided to unilaterally terminate BITs with some EU member states such as Belgium and Luxembourg, Spain, Germany, Switzerland, and the Netherlands. It seeks to sign new investment protection agreements with these states on the basis of local laws. Abandoning BITs can negate South Africa's potential international obligations over public policies designed for social redress. The government replaced these BITs with the Promotion and Protection of Investment Act 2015, which is rooted in South Africa's Constitution and gives more policy space to the government and an apparent advantage over the restrictive and outdated BITs. The driving force of this overhaul is the likelihood of the government being brought before the international court of arbitration over some controversial public policies such as the Broad-based Black Economic Empowerment and land redistribution policies.

The EU views such a move as hostile and symptomatic of "emerging protectionism" in South Africa, which however argues that the Constitution is the supreme law of the law and is sufficient to offer protection to foreign investors. The host state government can either screen foreign investment by relying on a national security review or designate some sectors of the economy as strategic so as to keep them off-limits to foreign investors.

More countries have been and are in the process of reviewing their model BITs and renegotiating existing BITs for the purpose of striking a new balance between foreign investors and home states.

Latin American countries had a strong tradition of keeping a distance from the World Bank and the ICSID in the 1960s and 1970s when almost all of these countries voted against the idea of having the ICSID. ${ }^{85}$ Terfor instance, VINCENTELLI, Ignacio A. The uncertain future of 
minating BITs itself is an exercise of a host state's sovereign power. On March 11, 2011, Bolivia, Colombia, Ecuador, Peru, Argentina, Brazil, Paraguay, Uruguay, Chile, Guyana, Suriname, and Venezuela formed the Union of South American Nations (UNASUR), one of whose future goals is to establish an international investment arbitration forum that recognizes the distinct nature of these emerging economies. ${ }^{86}$ The proposed framework includes various Latin America-favored components such as hearings being held in an official South American language, the forum being used after the exhaustion of local remedies, transparency with documents and hearings being made available, and an appeal system. ${ }^{87}$

Although the ISDS is a non-majoritarian institution in international law, the majoritarian difficulty is clear while rule of law is backsliding and global rule of law is decaying. The concept of legitimacy is broadly used in today's discourse about populism in order to suggest that certain institutions set up by populists or subject to their hostile takeover have become illegitimate. The notion of legitimacy has been under attack in international investment law even though legitimacy has been largely achieved through the investor-state dispute settlement mechanism by reference to social justice and progressive policies in general.

The dimensions of legal political have changed. A new conflict between nationalist and socially conservative versus cosmopolitan and socially progressive positions has emerged. Populist governments, representing populist people (and their true interests at large) and positioning themselves on the new dimension of legal conflict, campaign on anti-establishment. Populist ideo$\operatorname{logy}$ is a reaction to economic distress which is systemically correlated with economic insecurity and adverse trade shocks.

ICSID in Latin America. Dec. 19, 2009. Available at: http://works. bepress.com $/ \mathrm{cgi} /$ viewcontent.cgi?article $=1000 \&$ contex $\mathrm{t}=$ ignaci O_vincentelli. Access: Jan. 5, 2019.

86 GOMEZ, Katia Fach. Latin American approach to international dispute resolution. American Society of International Law Meeting in Washington. Mar. 25, 2011. Available at: http://www. academia,edu/830249/latin_American_Approaches-to_International_Dispute_Resolution. Access: Jan. 9, 2019.

87 GOMEZ, Katia Fach. Latin American approach to international dispute resolution. American Society of International Law Meeting in Washington. Mar. 25, 2011. Available at: http://www. academia,edu/830249/latin_American_Approaches-to_International_Dispute_Resolution. Access: Jan. 9, 2019.
In the past, economic adversity triggered a demand for protection through the welfare state, which benefited social democratic parties and reinforced the trade unions. Now adverse economic shocks push voters towards socially conservative politicians that campaign on platforms of welfare state retrenchment and are not paladins of redistributive economic policies. In the absence of other political options, the losers from globalization and technological advances turned towards the new populist parties.

\section{State Is Back!}

Populism is often packaged in the form of nationalism. Therefore, the other indirect consequence of the rise of populism is the change in power balance of multinational corporations, which used to be the most important private actors in transnational legal governance. State-owned enterprises (SOEs) and sovereignty wealth funds (SWFs) have now emerged to be the new dominant actors in the Global South to enable or perpetuate relationships between international law and authoritarianism.

Sovereignty is an issue of international law that constantly deserves revisits. International law has long struggled with the problem of how makers of international law can also be bound by it. ${ }^{88}$ International law as a concept rests on the traditional notion of states which are arisen from the Westphalian system. As the nature of sovereignty and its relationship with law evolves, the foundation of the sovereignty concept also changes. For example, the emergence of international human rights law has challenged the classical conceptualization of sovereignty, which asserts that a sovereign government has absolute legal authority within its territory over its citizens. ${ }^{89}$ The recent intensification of globalization has further challenged international law which governs relations among sovereign states and private actors. The increasing popularity of international investment arbitration cases, which are essentially claims initiated by commercial actors against state governments, has also

\footnotetext{
88 E.g., SCOT'T, Shirley V. International law in world politics: an introduction. London: Lynne Rienner Publishers, 2010. p. 19-27; ANGHIE, Antony. Rethinking sovereignty in international law. Annual Review of Law and Social Science, v. 5, p. 291, 2009.

89 POSNER, Eric A. The perils of global legalism. Chicago; London: University of Chicago Press, 2009. Ch. 8.
} 
distorted the power relationship between sovereignty and private commercial entities which frequently participate in international commerce based on the triumph of the "free market" concept. International law has not been a closed legal system containing a fixed tally of actors on the international scene..$^{90}$ Instead, increasing participation of new international actors in international commerce, for example, multinational corporations, sovereign wealth funds, international organizations, and non-profit entities, most of them being termed controversial candidatures, ${ }^{91}$ have changed the picture of global economic governance and international legal system $^{92}$ which in the past was mostly dominated by sovereignty actors. ${ }^{93} \mathrm{New}$ issues in state responsibilities also constantly arise after the occurrence of large-scale financial crises in regions like East Asia, Latin America and the Middle East. ${ }^{94}$

However, some most important debates concerning the changing concept of sovereignty are raised after the 2008-2009 financial crisis, which caused a dramatic increase in state economic intervention both by the developed and developing nations. This so called phenomenon of return of "state capitalism" has been accompanied by the remarkable comeback of public wealth, public investment and public enterprises. ${ }^{95}$ State government starts to interfere more deeply with private economic activities by nationalizing private industries and creating more state owned investment entities. ${ }^{96}$ For example, in 2010 the United Kingdom, which has tra-

90 BROWNLIE, Ian. Principles of public international law. 5. ed. Oxford: Clarendon Press, 1998. p. 66-67.

91 BROWNLIE, Ian. Principles of public international law. 5. ed. Oxford: Clarendon Press, 1998. p. 66-67.

92 In other international law arenas, the emergence of new actors such as private military and security companies has created new challenges for international humanitarian law. THÜRER, Daniel. International humanitarian law: theory, practice, context. Hague: Hague Academy of International Law, 2011. p. 252.

93 HIGGNS, Rosalyn. Problems and process: international law and how we use it. Oxford: Clarendon Press, 1994. p. 39.

94 E.g., in a number of cases American investors filed against Argentina on claims arisen from breaches of US-Argentina BIT including CMS Gas Transmission Company v. Argentina Republic (Merits) (12 May 2005), 44 ILM 1205, state responsibility under international law to ensure a stable and predictable environment for foreign investors in the midst of financial downturn was repeatedly raised as an issue.

95 BREMMER, Ian. The return of State capitalism. Survival: Global Politics and Strategy, v. 50, n. 3, p. 55, 2008.

96 MCNAMARA, Tom. Foreign sovereign immunity during the new nationalisation wave. Business Law International, v. 11, n. 1, p. 5-38, 2010. ditionally embraced liberalist economic principles, took up major shares of its two global financial institutions, the Lloyds Banking Group and Royal Bank of Scotland, during this movement toward nationalization.

State-directed capitalism is not a new phenomenon, and the colonial era witnessed State Owned Enterprises (SOE) such as East India Company's overseas expansion. In some of the world's major economies, including China and Russia today, state-backed companies have accounted for more than $2 / 3$ of these countries' stock market value. ${ }^{97}$ As this new wave of state capitalism took place in various forms, the recent rise of Sovereign Wealth Funds (SWFs), a transnational investment vehicle of states that are distinguishable from traditional state controlled investment vehicles, deserves some attention..$^{98}$ Some developing states, flush with money as a result of flows of profits resulting from economic globalization such as imbalances of global trading and capital flows, have created funds for making investments in developed or developing countries with their surplus capital. These states include smaller city states like Singapore whose SWFs survive on large amount of foreign reserves, Dubai whose SWFs mainly come from the country's oil revenues, and Uganda that has attracted huge volume of international donation, ${ }^{99}$ but apparently, the most dramatic rise was that associated with China. This seems to recall the importance of an old principle, demonstrating the possibility of a state's dual role as simultaneously sovereign and "corporate", depending on the nature of its action.

The first SWF was established in Kuwait and named Kuwait Investment Authority in the year of 1953. It remains one of the largest SWFs based on an estimate of its overall assets. There is no uniform definition for SWF. The IMF made an attempt to distinguish the SWF on its functions and objectives by defining SWF as "special purpose investment funds or arrangements owned by the general government" 100 while the World (IWG). Sovereign Wealth Funds Generally Accepted Principles and Practices 
Bank suggested them to be "long term investment funds typical for both income and intergenerational wealth transfer." 101 On the other hand, although SOEs and SWFs both invested in economic markets abroad, SOEs like to seek controlling interests in investment target by the way of acquisition of control of a private economic entity, the investment purposes of SWFs apparently are more diverse. ${ }^{102}$ For example, some works specify that the pool of money of SWF must be managed by a government sovereign entity in the sense that it has foreign currency exposure, without explicit liabilities, and must have a high risk tolerance, or a long investment horizon. ${ }^{103}$

Today, the role and scale of SWFs in cross border investment activities have become more visible. So do sovereign nations in the scale of their penetration into the global financial market. Through a group of SWFs, sovereign owners are more capable of mobilizing their economic resources and coordinating economic activities to achieve economic and sovereign goals. According to an IMF estimate, the overall assets held by SWFs was only about US $\$ 0.5$ billion in the early 2000 s, and have grown very rapidly in the last 10-15 years. SWFs now manage US $\$ 7$ trillion assets. ${ }^{104}$ Although most SWFs choose to behave quite low key in their investment patterns, they have started to gain more attention after some of the largest transactions involving SWFs from developing nations appeared in the Western media. The controversial investment of $\mathrm{CNOOC}^{105}$ and

'Santiago Principles'. 2008.; GAUKRODGER, David. Foreign state immunity and foreign government controlled investors. OECD Working Papers on International Investment, 2010. Available at: https://www.oecd. org/corporate/mne/WP-2010_2.pdf.

101 MITCHELL, Olivia S.; PIGGOTT, John; KUMRU, Cagri. Managing public investment funds: best practices and new challenges. National Bureau of Economic Research Working Paper No. 14078, 2008. Available at: https://www.business.unsw.edu.au/researchsite/australianinstituteforpopulationageingresearch-site/Documents.

102 MITCHELL, Olivia S.; PIGGOTT, John; KUMRU, Cagri. Managing public investment funds: best practices and new challenges. National Bureau of Economic Research Working Paper No. 14078, 2008. Available at: https://www.business.unsw.edu.au/researchsite/australianinstituteforpopulationageingresearch-site/Documents.

103 JEN, Stephen. Sovereign wealth funds: what they are and what's happening. World Economics, v. 8, n. 1, p. 1-2, 2007.

104 Sovereign Wealth Fund Institute. Fund rankings. 2014. Available at: http://www.swfinstitute.org/fund-rankings.

105 CNOOC is not a SWF by definition, but according to the controlling interests of $70 \%$ it could be approximated as an SWF in order to simplify the analysis. See generally COHN, Theodore H. Global political economy. 6. ed. Longman, 2012. Ch. 9.
Dubai Ports World ("DPW") in 2005 and 2006 that was blocked in the Unites States for failing to pass CFIUS's national security review has raised public awareness of SWF investments. This awareness intensified after the 2007 financial crisis during which period significant members of the world's financial community including the Citigroup, Merrill Lynch, Morgan Stanley, the Standard Chartered Bank, and UBS accepted large influxes of cash from SWFs. ${ }^{106}$ In 2010, 20 countries decided to establish their own SWFs. An overwhelming majority of the 20 countries are developing countries or so called emerging market countries. ${ }^{107}$ As of the end of 2018 and according to the estimate, the overall assets held by the world's largest SWF alone (Norway's Government Pension Fund - Global) is US\$10 trillion. ${ }^{108}$ According to the US Government Accountability Office Report, SWFs were projected to hold assets worth US $\$ 17$ trillion (roughly the size of the US economy) by $2017 .{ }^{109}$ In contrast, the total assets under management of private equity firms, which are far more numerous than SWFs, are estimated to be only approximately US $\$ 3.8$ trillion as of 2014, with only some very large firms approaching US\$50 billion. ${ }^{110}$

Although Western countries remain suspicious of investment activities conducted by SWFs, especially with reference to national security, corporate governance and financial stability issues, the advantages of this kind of state investments could not be ignored. First of all, SWFs with large inflow of cash investment are important resources of finance for companies who suffered distresses during the financial crisis. In addition, the participation of SWFs in worldwide investment activities links the interests of capital exporting countries with capital importing countries. For example, when a

106 O'BRIEN, Clare; MATTEI, Tania; THOMAS, Naveen. Sovereign wealth funds: evolving perceptions and strategies, securities \& regulation law report. Bloomberg BNA Securities and Law Report, v. 44, n. 50, p. $1,2012$.

107 UNCTAD. World Investment Report. 2011. Available at: http:// unctad.org/en/PublicationsLibrary/wir2011_en.pdf.

108 NORWAY wealth fund grows to record 10 trillion crowns. Reuters, Oct. 25, 2019. Available at: https://www.reuters.com/article/us-norway-swf-record/norway-wealth-fund-grows-to-record10-trillion-crowns-idUSKBN1X41AO.

109 CANUTO, Otaviano; GIUGALE, Marcelo (eds.). The day after tomorrow: a handbook on the future of economic policy in the developing world. Washington DC: The World Bank, 2010.

1102015 Preqin Global Private Equity \& Venture Capital Report - Sample Pages. Available at: https://www.preqin.com/docs/ reports/2015-Preqin-Global-Private-Equity-and-Venture-Capital-Report-Sample-Pages.pdf. 
Chinese SWF invests in a UK bank, China has a vested interest in the performance of the UK economy. ${ }^{111}$

Accompanied by the "Go Globally" strategy" and the Belt and Road Initiative, the Chinese government has employed a combination of investment strategies by engaging its SWFs to conduct overseas investment as a way to maximize state wealth and reputation, and investing abroad to secure access to natural resources. Energy and metals are principal investment areas and account for nearly $70 \%$ of outflows since $2005 .{ }^{113}$ In 2019, China's outbound mergers and acquisitions in the power and utilities sector was US $\$ 9.5$ billion. ${ }^{114}$

Apart from the SWFs, the main form of state investment is the state-owned enterprises or SOEs. Through the form of SOEs, sovereigns are able to act as owners and investors and operate businesses and assets in a corporate veil like privately owned companies. There is little difference in functionality between SWFs and SOEs. Both represent the core of networks of public-private investment coordination in which wealth or profit maximization is blended with political objectives directed by the state even though there exist a variety of subtle differences between SWFs and SOEs as listed in Table 2 below. Chinese SOEs are sovereign in the sense that their ownership vest, directly and indirectly, in the state, and direct state oversight. Recently both state ownership and state oversight were reduced given the policy to separate government functions from business operations. SWFs however have not considerably reduced state ownership and state oversight. SOEs nowadays are no longer corporate expressions of publicly controlled economic activity, and function like privately held enterprises. Related to the key theme covered in this article, the issue of sovereign immunity probably

111 DE MEESTER, Bart International legal aspects of sovereign wealth funds: reconciling international economic law and the law of state immunities with a new role of the State. Institute for International Law Working Paper No. 20, 2009. Available at: http://ssrn.com/abstract $=1308542$.

112 For a general description of China's "Go Globally" strategy, which consists of a serious of national policy incentives that are used by the Chinese government to encourage its companies to invest abroad, see ALON, Ilan; WANG, Hua; SHEN, Jun; ZHANG, Wenxian. Chinese State-owned enterprises go global. Journal of Business Strategy, v. 35, n. 3, p. 3-18, 2014.

113 GURRIA, Angel. China go global. OECD, Mar. 24, 2014. Available at: https://www.oecd.org/china/china-go-global.htm.

114 E\&Y. Overview of China outbound investment in 2019. Feb. 13, 2020. Available at: https://www.ey.com/cn/en/newsroom/news-releases/news-2020-ey-overview-of-china-outbound-investment-in-2019. does not arise if one transacting party is an SOE, which is neither a foreign state nor likely to be considered as part of the PRC government. This is the position in the PRC where SOEs do not enjoy immunity and may be sued in the PRC courts. Unless an SOE is carrying out a function of the state, it is not likely to be considered as part of the state, and absolute sovereign immunity is not likely to be an issue. 
Table 2 - Comparison between Chinese SWFs with Chinese SOEs

\begin{tabular}{|c|c|c|}
\hline Perspectives & $\begin{array}{l}\text { Sovereign Wealth } \\
\text { Funds }\end{array}$ & $\begin{array}{l}\text { State Owned } \\
\text { Enterprises }\end{array}$ \\
\hline State Ownership & $\begin{array}{l}\text { Central Chinese } \\
\text { Government }\end{array}$ & $\begin{array}{l}\text { Central Chinese } \\
\text { Government or } \\
\text { Local Governments }\end{array}$ \\
\hline $\begin{array}{l}\text { Source of } \\
\text { Funding }\end{array}$ & $\begin{array}{l}\text { Foreign Reserve/ } \\
\text { Export and } \\
\text { Investment Profits }\end{array}$ & $\begin{array}{l}\text { State Treasury } \\
\text { Budget }\end{array}$ \\
\hline $\begin{array}{l}\text { Investment } \\
\text { Portfolio }\end{array}$ & Diversified & $\begin{array}{l}\text { Controlling } \\
\text { Interests in } \\
\text { Investment Targets }\end{array}$ \\
\hline State Oversight & Direct & Direct or indirect \\
\hline $\begin{array}{l}\text { Investment } \\
\text { Pattern }\end{array}$ & $\begin{array}{l}\text { Largely passive, } \\
\text { shareholder } \\
\text { inactivism due to } \\
\text { regulatory and } \\
\text { political constraints }\end{array}$ & $\begin{array}{l}\text { Largely active, } \\
\text { shareholder } \\
\text { activism }\end{array}$ \\
\hline $\begin{array}{l}\text { Government } \\
\text { Control }\end{array}$ & Full & Partial \\
\hline Corporate Form & $\begin{array}{l}\text { Instrumentality of } \\
\text { the state }\end{array}$ & $\begin{array}{l}\text { Separate legal } \\
\text { personality }\end{array}$ \\
\hline Transparency & $\begin{array}{l}\text { Usually Low (CIC } \\
\text { being highest) }\end{array}$ & $\begin{array}{l}\text { Usually high } \\
\text { for public listed } \\
\text { companies }\end{array}$ \\
\hline Examples & CIC, SAFE & CNOOOC \\
\hline Goals & Sovereign goals & Economic goals \\
\hline $\begin{array}{l}\text { Governing } \\
\text { International } \\
\text { Rules }\end{array}$ & $\begin{array}{l}\text { Sovereignty and } \\
\text { immunity rules }\end{array}$ & $\begin{array}{l}\text { Restrictive } \\
\text { immunity rule }\end{array}$ \\
\hline
\end{tabular}

As a communist state, China has a long history of conducting overseas investment through state owned investment entities. However, China's first SWF - China Investment Corporation (CIC) was not incorporated until 2007 in order to manage some of the country's "massive foreign exchange reserves." It has become the second largest sovereignty wealth funds in the world with the total assets of US\$940,604 million, right after the Norway Government Pension Fund Global. ${ }^{115}$ According to the objective of CIC, it is a wholly state owned company established "as a vehicle to diversify China's foreign exchange holdings and seek maximum returns for its shareholder". ${ }^{116}$ Together with the National Social Security Fund, SAFE Investment Company (SIC) and China-Africa Investment Fund, these four entities are considered the most important SWFs in

115 SWFI. Top 89 largest sovereign wealth fund rankings by total assets. Available at: https://www.swfinstitute.org/fund-rankings/sovereign-wealth-fund.

116 For a summary of the purpose of CIC a reference to their website is provided, "About CIC", Available at: http://www.china-inv. $\mathrm{cn} / \mathrm{wps} /$ portal/.
China that are coordinating and competing in the global investment and financial markets, while the CIC is the only officially recognized SWF in China. ${ }^{117}$

Overall, investment of Chinese major SWFs could be classified into three brief periods. During the first stage of between 2007 and 2009, investment of Chinese SWFs was primarily concentrated in the high-risk financial sectors by infusing a large amount of money in European and American Reserve banks. For example, CIC has invested about US $\$ 10$ billion in American hedge funds Blackstone and Morgan Stanley since 2007. ${ }^{118}$ As a result of the crisis brought about by sub-prime lending, lots of China's investments in foreign banks and financial institutions went bad. Investments in Morgan Stanley, Fannie Mae and Freddie Mac burned these funds badly. ${ }^{119}$ To recover economic losses and reshape investment strategies, the Chinese SWFs appointed an advisory board of economic and investment experts to provide counsel on international economic environment, corporate governance, development strategy, and investment policy, as well as upgrading and improving their corporate image and increasing transparencies. ${ }^{120}$ Learning from the mistakes of the first period, during the second stage roughly between 2009 and 2012, Chinese SWFs started to invest more heavily though the acquisition of shares in existing companies in developed countries, and in more diversified areas including real estate, natural resources and agriculture, and have started to conduct longer term investment in developing countries. Since 2012, more Chinese SWFs become interested in high-tech areas and combined portfolio investments. Chinese SWFs are also heavily interested in investing in public sectors including health care, education and materials. This diversification of the investment portfolio was undertaken to reduce investment risks. For example, in 2014, CIC invested US\$1.6

117 CIEŚLIK, Ewa. Investment strategy of sovereign funds from emerging markets: the case of China. Bulletin of Geography: SocioEconomic Series, v. 24, p. 27-28, 2014.

118 KOCH-WESER, Iacob N.; HAACKE, Owen. China investment corporation: recent developments in performance, strategy, and governance paperback. CreateSpace Independent Publishing Platform, 2014.

119 KOCH-WESER, Iacob N.; HAACKE, Owen. China investment corporation: recent developments in performance, strategy, and governance paperback. CreateSpace Independent Publishing Platform, 2014.

120 KOCH-WESER, Iacob N.; HAACKE, Owen. China investment corporation: recent developments in performance, strategy, and governance paperback. CreateSpace Independent Publishing Platform, 2014. 
billion dollars in the London Heathrow Airport, which has made it one of the major controlling investors of Heathrow Airport Holdings together with a number of other SWFs including Qatar Holding and GIC. ${ }^{121}$ There has also been a switch to indirect investments which are conducted through subsidiaries and partnership companies of SWFs providing financial assistance to Chinese overseas companies. As one of the drafters of Santiago Principles, CIC has been seen to have implemented these principles in good faith. ${ }^{122}$ Therefore, the Chinese efforts to coordinate sovereign investment through coordinating its SWFs present a potentially substantial advance in the integration of programs of sovereign investing, public policy, and private markets. This integration suggests that it may be possible for a state to employ a policy of politically motivated interventions in foreign markets and markets for control that is, simultaneously, financially motivated.

As a financial hub, Hong Kong remains strategically important to Chinese outbound investment although destinations including the United States, Australia, and South Korea have started to catch up as these places receiving FDIs with Chinese origins. Hong Kong had a laissez-faire policy which is aimed at promoting barrier-free trade and investment. In addition, Hong Kong enjoys a unique advantage under the Mainland-Hong Kong Closer Economic Partnership Arrangement which was first concluded in June $2003^{123}$ with the purpose of promoting closer economic collaboration between two sides. Under the CEPA, prominent preferential liberalizations for goods and services of Hong Kong to enter the China market was announced and it in general has provided better terms than China's WTO commitments. ${ }^{124}$ According to UNCTAD World Investment Report 2015, Hong Kong remains the second largest economy for FDI outflows and the key entrepot of Chi-

121 PEREZ, Santiago. Qatar holding buys 20\% stake in BAA for $\$ 1.4$ billion. The Wall Street Journal, 17 Aug. 2012. Available at: http:/ / www.wsj.com/articles/SB1000087239639044437510457759524297 7156080 .

122 CARR, Chris. 'National interest' concerns and uncertain investment regime are impeding important investments by sovereign wealth funds. Harvard Business Review Online, v. 67, n. 3 2013. Available at: http://www.hblr.org/wp-content/uploads/2013/03/Carr_ National-Interest-Concerns.pdf.

123 Law of the People's Republic of China on Judicial Immunity from Measures and Constraints of the Property of Foreign Central Banks, Law on Judicial Measures Over Assets of National Bank (2005).

124 Mainland and Hong Kong Close Economic Partnership Act (2003). na. ${ }^{125}$ According to official government statistics of Hong Kong, China was the destination of 53.7 percent of Hong Kong's re-exports in the year of 2015, which means that a majority of the direct investments in China are channeled through Hong Kong. ${ }^{126}$ The presence of large amount of assets of SOEs of China in Hong Kong have posed serious threats that these assets are going to be subject to collection efforts of foreign creditors, as Hong Kong's common law tradition and its robust legal system has ensured the possibility of Chinese enterprises being sued in Hong Kong, statistics have shown that at least 9 Chinese SOEs had to defend themselves in Hong Kong CFA through the years of 2005 to $2015 .{ }^{127}$

In the socio-ethnographic research conducted by Ching Kwan Lee over Chinese state capitalism in Zambia, she argued that Chinese SOEs not only seek profit-maximizing but also to pursue "the nation's strategic, lifeline, security interests" through political patronage, influence, and access to communities. ${ }^{128}$ Actually, most of the international reporting systems are not applicable to China. As it is not currently a member of the OECD it does not need to follow the OECD Reporting System. Nor does it belong to the UN Conference on Trade and Development's 2012 "Principle on Promoting Responsible Sovereign Lending and Borrowing". China's policy banks which finance the majority of its SWF overseas investments, including most of ongoing Belt and Road Initiative ("BRI") projects, are a black box of governance, at least to Western investors. This form of stack-backed capitalism, labelled as a form of populism ${ }^{129}$ and utilized to boost diplomatic and political interests of the party-state, are distorting the current international financial order designed to maintain the balance between profit-seeking private companies and

125 UNCTAD. World Investment Report 2015. Available at: http:// unctad.org/en/PublicationLibrary/wir2015_en.pdf.

126 HKTDC. Economic and trade information on China. 14 Mar. 2016. Available at: http://china-trade-research.hktdc.com/businessnews/article/Fast-Facts/Economic-and-Trade-Information-onChina/ff/en/1/1X000000/1X09PHBA.htm.

127 Data gathered from Hong Kong Court of Final Appeal Judgments in Decided Cases. Available at: http://www.hkcfa.hk/en/ work/cases/judgments/index.html.

128 LEE, Ching Kwan. The specter of global China: politics, labor, and foreign investment in Africa. 2018. p. 32-33.

${ }^{129}$ HEDRICK-WONG, Yuwa. China, populism, and the demise of the liberal global economic order. Forbes, Nov. 3, 2019. Available at: https://www.forbes.com/sites/yuwahedrickwong/2019/11/03/ china-populism-and-the-demise-of-the-liberal-global-economicorder/\#4ff034a37682. 
important interests of less developed nations.

The recently concluded DP World v. Djibouti arbitration case is an excellent illustration of such tension presented. In 2014, DP World Djibouti FZCO filed an arbitration claim against the government of Djibouti before the London Court of International Arbitration ("LCIA"), seeking damages, interest and restoration of its right of development according to a concession agreement giving DP World exclusive control over all ports in Djibouti. ${ }^{130}$ The concession agreement entered into between DP World and Djibouti back in 2004 provided DP World with control over Djibouti ports for a thirty-year period. Due to disagreement arisen between the two parties during the cooperation, in 2012 Djibouti signed an agreement with China Merchants for new developments of its ports. In early 2018 Djibouti terminated its contract with DP World through a presidential decree and nationalized all of its assets, even though it continued to pursue projects with the China Merchants. DP World accused the Djibouti government of illegally breaching the concession contract, and brought arbitration against it at the LCIA. In 2018, an LCIA tribunal rendered its decision in favor of DP World, asking Djibouti to restore DP World's rights to run the projects for the remaining term under the concession. However, the Djibouti government has in a public statement openly refused to honor the arbitral award in defending its nation's highest interests. ${ }^{131}$ To many, this represents the growing influence of China over African nations due to its strong financial capacity to invest through state-owned vehicles, which blends new form of geopolitical relationship backed by access to large amount of credit in domestic politics. ${ }^{132}$ These vehicles are actively influencing or even shaping international legal norms and practices, the new ones most friendly to state interests they represent.

Private corporations and multinational enterprises ("MNEs"), on the other hand, challenged by populist and anti-globalization sentiment and unprecedented

\footnotetext{
130 DP World Djibouti FZCO v. Djibouti, London Court of International Arbitration.

131 DJIBOUTI rejects court ruling to hand back container terminal. The Wall Street Journal, Jan. 17, 2020. Available at: https:// www.wsj.com/articles/djibouti-rejects-court-ruling-to-hand-backcontainer-terminal-11579296713.

132 DJIBOUTI rejects court ruling to hand back container terminal. The Wall Street Journal, Jan. 17, 2020. Available at: https:// www.wsj.com/articles/djibouti-rejects-court-ruling-to-hand-backcontainer-terminal-11579296713.
}

expansion of state-backed investment vehicles, are struggling with increasing transaction costs when they come to deal with the markets and supply chains. Taking into account these nonmarket threats and uncertainties, MNEs have to re-strategize or re-engineer their growth in a much more tightly controlled legal framework. The new wave of nationalism and protectionism creates a salient need for more investigation into the nonmarket threats and strategies. Under this narrative, MNEs are now operating their businesses in an environment of nationalist rhetoric and mercantilist behavior. Increased anti-globalization sentiment and legislation (including those in disguise of national security) require MNEs to adjust and adapt their corporate strategies. They are facing political risk and regulatory uncertainty stemming from government policies in nationalist and protectionist nature.

Threatened by the rise of these transnational vehicles, MNEs in their more transparent structure can develop strategies and statics to manage and mitigate anti-global challenges. In order to enhance competitive advantages in contexts where nationalism and geopolitical risk is at a high stake, transnational private governance may need to be reconceptualized, preparing for legal changes and lawful responses in these contexts. Hopefully we can generate new theoretical insights into the relationship between nonmarket threats and lawful responses in relation to government policies, socio-political risk, institutional uncertainty, and an anti-global business environment.

\section{Conclusions}

Populism can be viewed as an ideology, a discourse, a movement, or a political strategy. In the spirit of its ambiguity, it is worth theorizing populism, and discussing theories of populism that challenge or extend the existing norms, rules and regimes. There appears a new generation of populists on the global stage, offering contradictory and disturbing visions regarding the world's future. ${ }^{133}$ The debate over the role of globalization, sustainable development, ${ }^{134}$ rule of law and global ment. German Development Institute Briefing Paper 8/2019. Available at: 
justice indicates the institutional weakness and resilience of domestic or international mechanisms.

Conflicts in populism centres on globalization and polarization, ${ }^{135}$ at least in the areas of international law and global governance. ${ }^{136}$ The accelerated diffusion of populism after the latest global financial crisis cannot be a coincidence. Past financial crises were usually followed by a radicalization of political ideologies as well as by the rise of new extremist social movements. A financial crisis can easily turn the blame onto the political and economic establishment. As globalization is closely interconnected with global financial crisis, they both create shocks and take blames.

The core of the populist ideology has profoundly reshaped social and political cleavages at the national and international level. ${ }^{137}$ Both the national and international politics are confronted with populist movements that challenge their technocratic and nationalist frameworks. The failures of globalization projects have provoked contestations today.

The rise and spread of populism pose a vital threat to the world order. We discussed challenges posed by the growing influence of populism to bilateral relationships, international mechanisms, and transnational private actors. National politicians advocate or pursue the dismantling of international institutions by taking steps backwards. The justification of this claim rests on the complaint over globalization. However, solutions cannot be found by reverting to unilateralism. Some of the most pressing policy issues require global solutions. International institutions need to be enhanced and tasked with a much broader scope of duties so as to gain more legitimacy. The populist movement is taking the world order to the opposite direction of globalization. In the years to come, we may see a much more populist, fragmented and state-centric world order.

https://www.die-gdi.de/uploads/media/BP_8.2019.pdf.

135 HANDLIN, Samuel. The logic of polarizing populism: state crises and polarization in South America. Sage Journals, 2018. Available at: https://journals.sagepub.com/doi/ full/10.1177/0002764218756922.

136 OFFICE OF THE REGIONAL CHIEF ECONOMISTS. Polarization and populism: Europe and Central Asia economic update. Nov. 2016. Available at: http://documents.worldbank.org/curated/ en/494811479976405381/pdf/Polarization-and-populism.pdf.

137 MÜLLER, Philipp; SCHEMER, Christian; WETTSTEIN, Martin; SCHULZ, Anne; WIRZ, Dominique S.; ENGESSER, Sven; WIRTH, Werner. Populist attitudes in the public: evidence from a panel study in four European democracies. Journal of Communication, v. 67, n. 6 , p. $968-992,2017$.
In an era of populism, along with tense instability, persistent uncertainty and fragile eco-structures, the politics of populism and an appeal to nationalism and unilateralism globally are endangering the liberal world order. ${ }^{138}$ Viewed as a feature of contemporary world politics, populism places global justice and rule of law at a high stake of risk. Given the limits in institutional development and stability, the old premise that inspired development of world order and international law in the past has opened up the liberal world order to illiberal values ${ }^{139}$ and regimes, ${ }^{140}$ and become brittle in the face of new global threats facing countries when they move from survival to sustainability. The ongoing coronavirus pandemic seems to suggest that, as predicted by some already, instability and populist unrest is the new world order. ${ }^{141}$

\section{References}

ACEVES, Williams J. The economic analysis of international law: transaction cost economics and the concept of state practice. University of Pennsylvania Journal of International Economic Law, v. 17, n. 4, p. 996-1068, 1996.

ACHAVAL, Clara Picasso. Tipping the balance towards investors. Journal World Investment and Trade, v. 9, p. 147$162,2008$.

ALON, Ilan; WANG, Hua; SHEN, Jun; ZHANG, Wenxian. Chinese State-owned enterprises go global. Journal of Business Strategy, v. 35, n. 3, p. 3-18, 2014.

ALSTON, Philip. The populist challenge to human rights. Journal of Human Rights Practice, v. 9, n. 1, p. 1-15, 2017.

AMERICA v. China Huawei and 5Geopolitics. The Economist, Apr. 11-17, 2020.

138 GRUBEL, Herbert. Is populism endangering the liberal world order? Sept. 10, 2019. Available at: https://ssrn.com/abstract $=3451416$.

${ }_{139}$ OSADA, Hiroki. The adamant world order: is populism a threat to the world order?. The Geopolitics, May 19, 2018. Available at: https://thegeopolitics.com/the-adamant-world-order-is-populismthreat-to-the-world-order/.

140 LEE, Michael. Populism or embedded plutocracy?: the emerging world order. Survival Global Politics and Strategy, v. 61, n. 2, p. 5382, 2019.

${ }^{141}$ BALZ, Dan. Instability and populist unrest is the new world order. The Washington Post, Dec. 12, 2018. Available at: https:// www.washingtonpost.com/politics/instability-and-populist-unrestis-the-new-world-order/2018/12/11/0959c858-fd7b-11e8-862ab6a6f3ce8199_story.html. 
ANGHIE, Antony. Rethinking sovereignty in international law. Annual Review of Law and Social Science, v. 5, p. 291, 2009.

BALIN, Bryan J. Sovereign wealth funds: a critical analysis. Johns Hopkins University School of Advanced International Studies, 2009. Available at: http://papers.ssrn. com/sol3/papers.cfm?abstract_id=1477725.

BALZ, Dan. Instability and populist unrest is the new world order. The Washington Post, Dec. 12, 2018. Available at: https://www.washingtonpost.com/ politics/instability-and-populist-unrest-is-the-newworld-order/2018/12/11/0959c858-fd7b-11e8-862ab6a6f3ce8199_story.html.

BARDHAN, Pranab. Populism in less developed countries is somewhat different. 3 Quarks Daily, Aug. 6, 2018. Available at: https://www.3quarksdaily. com/3quarksdaily/2018/08/populism-in-less-developed-countries-is-somewhat-different.html.

BEESON, Mark. Environmental populism: the politics of survival in the Anthropocene. Palgrave: MacMillan, 2019.

BELLO, Judith H.; HOLMER, Alan F. Special 301: its requirements, implementation, and significance. Fordham International Law Journal, v. 13, n. 259, 1990.

BEOGLIN, Nicolas. ICSID and Latin America: criticisms, withdrawals and regional alternatives. Comm for the Abolition of Third World Debt, Jul. 4, 2013.

BHAT, Rohit. Will India do away with investor state arbitration?. Aug. 23, 2017. Available at: http://arbitrationblog. kluwerarbitration.com/2017/08/23/will-india-awayinvestor-state-arbitration/. Access: Jan. 30, 2019.

BLOOM, Peter. We live in a populist age: but who are "the people"?". The Conversation, Aug. 9, 2018. Available at: https://theconversation.com/we-live-in-a-populistage-but-who-are-the-people-91793.

BREMMER, Ian. The return of state capitalism. Survival: Global Politics and Strategy, v. 50, n. 3, p. 55, 2008.

BROLMANN, Catherine M.; COLLINS, Richard; EL DROUBI, Sufyan; WESSEL, Ramses A. Exiting international organizations: a brief introduction. International Organizations Law Review, v. 15, n. 2, p. 243-263, 2018.

BROWNLIE, Ian. Principles of public international law. 5. ed. Oxford: Clarendon Press, 1998.

BROWNLIE, Ian. Principles of public international law. 6. ed. Oxford: Clarendon Press, 2003.

BUMP, Philip. Where the US has considered leaving or left international agreements under Trump. The $\mathrm{Wa}$ shington Post, June 30, 2018. Available at: https://www. washingtonpost.com/news/politics/wp/2018/06/29/ where-the-u-s-has-considered-leaving-or-left-international-agreements-under-trump/.

CANUTO, Otaviano; GIUGALE, Marcelo (eds.). The day after tomorrow: a handbook on the future of economic policy in the developing world. Washington DC: The World Bank, 2010.

CARR, Chris. 'National interest' concerns and uncertain investment regime are impeding important investments by sovereign wealth funds. Harvard Business Review Online, v. 67, n. 3 2013. Available at: http://www.hblr.org/ wp-content/uploads/2013/03/Carr_National-Interest-Concerns.pdf.

CIEŚLIK, Ewa. Investment strategy of sovereign funds from emerging markets: the case of China. Bulletin of Geography: Socio-Economic Series, v. 24, p. 27-28, 2014.

CLARK, Harry L. Dealing with U.S. extraterritorial sanctions with foreign countermeasures. U. PA. J. International Economics and Law, v. 20, n. 61, p. 63-64, 1999.

CLEMENTS, Kevin P. Authoritarian populism and atavistic nationalism: $21^{\text {st }}$-century challenges to peacebuilding and development. Journal of Peacebuilding \& Development, v. 13, n. 3, p. 1-6, 2018.

CLEVELAND, Sarah. Norm internalization and economic sanctions. 55 .

COHEN, David; GOLDMAN, Zachary. Like it or not, unilateral sanctions are here to stay. ASIL Unbound, 2019.

COHN, Theodore H. Global political economy. 6. ed. Longman, 2012.

COLANTONE, Italo; STANIG, Piero. The trade origins of economic nationalism: import competition and voting behavior in western Europe. American Journal of Political Science, v. 62, n. 4, p. 936-952, 2018.

DELAUME, Feorges R. ICSID and the Banker. International Financial Law Review, v. 2, n. 9, p. 13, 1983.

DE MEESTER, Bart International legal aspects of sovereign wealth funds: reconciling international economic law and the law of state immunities with a new role of the State. Institute for International Law Working Paper No. 20, 2009. Available at: http://ssrn.com/ab- 
stract $=1308542$.

DIPPEL, Christian; GOLD, Robert; HEBLICH, Stephan. Globalization and its (dis-)content: trade shocks and voting behavior. NBER Working Paper 21812, 2015. Available at: http://www.nber.org/papers/w21812.

DJIBOUTI rejects court ruling to hand back container terminal. The Wall Street Journal, Jan. 17, 2020. Available at: https:/ /www.wsj.com/articles/djibouti-rejects-courtruling-to-hand-back-container-terminal-11579296713.

EGLI, Gabriel. Don't get bit: addressing ICSID's inconsistent application of most-favored-nation clauses to dispute resolution provisions. Pepperdine Law Review, v. 34, p. 1045-1084, 2007.

EL-KADY, H. Egypt's bilateral investment treaties: a straitjacket in a new era of foreign investment reregulations?. Dec. 12, 2011. Available at: https:// www.transnational-dispute-management.com/Article asp?key=1826\#citation. Access: Jan. 29, 2019.

E\&Y. Overview of China outbound investment in 2019. Feb. 13, 2020. Available at: https://www.ey.com/cn/en/ newsroom/news-releases/news-2020-ey-overview-ofchina-outbound-investment-in-2019.

FIEZZONI, Silvia Karina. The challenge of UNASUR member countries to replace ICSID arbitration. Beijing Law Review, v. 2, p. 134-136, 2011.

FRIEDEN, Jeffry. The backlash against globalization and the future of the international economic order. In: The next phase of globalization: capitalism and inequality in the industrialized world. 2018.

GAUKRODGER, David. Foreign state immunity and foreign government controlled investors. OECD Working Papers on International Investment, 2010. Available at: https:// www.oecd.org/corporate/mne/WP-2010_2.pdf.

GOMEZ, Katia Fach. Latin America and ICSID: David versus Goliath. Law and Business Review of the Americas, v. 195, p. 195, 2011.

GOMEZ, Katia Fach. Latin American approach to international dispute resolution. American Society of International Law Meeting in Washington. Mar. 25, 2011. Available at: http://www.academia,edu/830249/latin_American_ Approaches-to_International_Dispute_Resolution. Access: Jan. 9, 2019.

GOODMAN, Charity L. Uncharted waters: financial crisis and enforcement of ICSID Awards in Argentina.
University of Pennsylvania Journal of International Economic Law, v. 28, p. 449-483, 2007.

GRUBEL, Herbert. Is populism endangering the liberal world order?. Sept. 10, 2019. Available at: https://ssrn.com/ abstract $=3451416$.

GURRIA, Angel. China go global. OECD, Mar. 24, 2014. Available at: https://www.oecd.org/china/china-goglobal.htm.

GURULE, Jimmy. The demise of the U.N. economic sanctions: regime to deprive terrorists of funding. Case W. Res. J. Int'L, v. 41, n. 19, p. 20-28, 2009.

HAMELEERS, Michael. Framing blame: toward a better understanding of the effects of populist communication on populist party preferences. Journal of Elections, Public Opinion and Parties, v. 28, n. 3, p. 380-398, 2018.

HANDLIN, Samuel. The logic of polarizing populism: state crises and polarization in South America. Sage Journals, 2018. Available at: https://journals.sagepub. com/doi/full/10.1177/0002764218756922.

HAYES, Alexander Rossell; DUDEK, Carolyn Marie. How radical right-wing populism has shaped recent migration policy in Austria and Germany. Journal of Immigrant \& Refugee Studies, v. 18, n. 2, p. 133-150, 2020.

HEDRICK-WONG, Yuwa. China, populism, and the demise of the liberal global economic order. Forbes, Nov. 3, 2019. Available at: https://www.forbes.com/ sites/yuwahedrickwong/2019/11/03/china-populism-and-the-demise-of-the-liberal-global-economicorder/\#4ff034a37682.

HIGGNS, Rosalyn. Problems and process: international law and how we use it. Oxford: Clarendon Press, 1994.

HKTDC. Economic and trade information on China. 14 Mar. 2016. Available at: http://china-trade-research.hktdc.com/business-news/article/Fast-Facts/ Economic-and-Trade-Information-on-China/ff/ en/1/1X000000/1X09PHBA.htm.

HONGRUI, Chen. The application of host state's law in international investment arbitration: the acceptability of article 30 of US model BIT. Journal of International Economic Law, Chen An ed., University Press, p. 162-167, 2010.

HUFE, Paul; KABUR, Ravi; PEICHL, Andreas. Measuring unfair inequality: reconciling equality of opportunity and freedom from poverty. CEPR Discussion Paper 12989, 2018. 
JEN, Stephen. Sovereign wealth funds: what they are and what's happening. World Economics, v. 8, n. 1, p. 1-2, 2007.

KARAMANIAN, Susan. International decision, Compania de Aguas del Aconquija S.A. \& Vivendi Universal S.A. v Argentine Republic. American Journal of International Law, v. 105, p. 553-555, 2011.

KEOHANE, Robert O. After hegemony. Princeton: Princeton University Press, 1984.

KOCH-WESER, Iacob N.; HAACKE, Owen. China investment corporation: recent developments in performance, strategy, and governance paperback. CreateSpace Independent Publishing Platform, 2014.

$\mathrm{KOH}$, Harold Hongju. The Trump administration and international law. Washburn Law Journal, v. 56, n. 413, p. 420, 2017.

LANG, Jonathan; GILFILLAN, Bowman. Bilateral investment treaties: a shield or a sword?. Nov. 8, 2013. p. 2-3. Available at: http://www.bowmanslaw. com/wp-content/uploads/2016/09/PPI-article_ mailshot_08112013_1038389_1-1.pdf. Access: Jan. 9, 2019.

LEE, Ching Kwan. The specter of global China: politics, labor, and foreign investment in Africa. 2018.

LEE, Michael. Populism or embedded plutocracy?: the emerging world order. Survival Global Politics and Strategy, v. 61, n. 2, p. 53-82, 2019.

LEMANN, Nicholas. The fate of populism in 2018. The New Yorker, Nov. 3, 2017. Available at: https:// www.newyorker.com/news/news-desk/the-fate-of-populism-in-2018.

LESTER, Simon; MANAK, Inu; KIM, Kyounghwa. Trump's first trade deal: the slightly revised Korea-US free yrade agreement. CATO Institute, June 13, 2019. Available at: https://www.cato.org/publications/freetrade-bulletin/trumps-first-trade-deal-slightly-revisedkorea-us-free-trade.

LISI, Marco. Populism, blame shifting and the crisis: discourse strategies in portuguese political parties. South European Society and Politics, v. 23, n. 4, p. 405-427, 2018.

MCNAMARA, Tom. Foreign sovereign immunity during the new nationalisation wave. Business Law International, v. 11, n. 1, p. 5-38, 2010.

MALAWER, Stuart S. Pending section 232 litigation and broader trade trends: will the US courts restrict presidential authority from relying upon national security? China \& WTO Review, v. 1, n. 183, p. 185, 2019.

MANCIAUX, Sébastien. The notion of investment: new controversies. Journal World Investment and Trade, v. 9, p. 443-444, 2008.

MIAN, Atif; SUFI, Amir; TREBBI, Francesco. Resolving debt overhang: political constraints in the aftermath of financial crises. American Economic Journal: Macroeconomics, v. 6, n. 2, p. 1-28, 2014.

MITCHELL, Olivia S.; PIGGOTT, John; KUMRU, Cagri. Managing public investment funds: best practices and new challenges. National Bureau of Economic Research Working Paper No. 14078, 2008. Available at: https:// www.business.unsw.edu.au/research-site/australianinstituteforpopulationageingresearch-site/Documents.

MÜLLER, Philipp; SCHEMER, Christian; WETTSTEIN, Martin; SCHULZ, Anne; WIRZ, Dominique S.; ENGESSER, Sven; WIRTH, Werner. Populist attitudes in the public: evidence from a panel study in four European democracies. Journal of Communication, v. 67, n. 6, p. 968-992, 2017.

NORRIS, Pippa; INGLEHART, Ronald. Cultural backlash: Trump, Brexit, and authoritarian populism. Cambridge: Cambridge University Press, 2019.

NORWAY wealth fund grows to record 10 trillion crowns. Reuters, Oct. 25, 2019. Available at: https:// www.reuters.com/article/us-norway-swf-record/ norway-wealth-fund-grows-to-record-10-trillioncrowns-idUSKBN1X41AO.

O'BRIEN, Clare; MATTEI, Tania; THOMAS, Naveen. Sovereign wealth funds: evolving perceptions and strategies, securities \& regulation law report. Bloomberg BNA Securities and Law Report, v. 44, n. 50, p. 1, 2012.

OFFICEOFTHEREGIONALCHIEFECONOMISTS. Polarization and populism: Europe and Central Asia economic update. Nov. 2016. Available at: http://documents. worldbank.org/curated/en/494811479976405381/pdf/ Polarization-and-populism.pdf.

OSADA, Hiroki. The adamant world order: is populism a threat to the world order?. The Geopolitics, May 19, 2018. Available at: https://thegeopolitics.com/the-adamantworld-order-is-populism-threat-to-the-world-order/.

PAASIVIRTA, E. Participation of states in international contracts and arbitral settlement of disputes. Helsinki: Finnish 
Lawyers’ Publishing Company, 1990.

PAPPAS, Takis S. Exchange: how to tell nativists from populists. Journal of Democracy, v. 29, n. 1, p. 148-52, 2018.

PASTOR, Lubos; VERONESI, Pietro. Inequality aversion, populism, and the backlash against globalization. NBER Working Paper 24900, 2019. Available at: http:// www.nber.org/papers/w24900

PEREZ, Santiago. Qatar holding buys 20\% stake in BAA for $\$ 1.4$ billion. The Wall Street Journal, 17 Aug. 2012. Available at: http://www.wsj.com/articles/SB10 000872396390444375104577595242977156080.

POPULISM: consequences for global sustainable development. German Development Institute Briefing Paper 8/2019. Available at: https://www.die-gdi.de/uploads/ media/BP_8.2019.pdf.

POSNER, Eric A. The perils of global legalism. Chicago; London: University of Chicago Press, 2009.

RAMPTON, Roberta. US withdraws from international accords, says UN World Court 'politicized'. Reuters, October 4, 2018. Available at: https://www.reuters. $\mathrm{com} /$ article/us-usa-diplomacy-treaty/us-reviewingagreements-that-expose-it-to-world-court-boltonidUSKCN1MD2CP.

ROLLAND, Sonia E. The return of state remedies in investor-state dispute settlement: trends in developing countries. Loyola University Chicago Law Journal, v. 49, n. 387, p. 395-399, 2017.

ROTH, Kenneth. The dangerous rise of populism: global attacks on human rights values. Human Rights Watch Global Report. 2017. Available at: https://www.hrw.org/ world-report/2017/country-chapters/dangerous-riseof-populism.

SANDS, Phillippe. Unilateralism, values and international law. EJIL, v. 11, p. 291-293, 2000.

SCOTT, Shirley V. International law in world politics: an introduction. London: Lynne Rienner Publishers, 2010.

SHAN, Wenhua. Is Calvo dead?. American Journal of Comparative Law, v. 55, p. 123-163, 2007.

SHIHATA, Ibrahim F. I. Towards a greater depoliticization of investment disputes: the roles of ICSID and MIGA. ICSID Review-Foreign Investment Law Journal, v. 1, n. 1, p. 24-25, 1986.
SORNARAJAH, M. The international law on foreign investment. 2. ed. Cambridge: Cambridge University Press, 2004.

SWFI. Top 89 largest sovereign wealth fund rankings by total assets. Available at: https://www.swfinstitute.org/fundrankings/sovereign-wealth-fund.

SYKES, Alan O. Constructive unilateral threats in international commercial relations: the limited case for section. 301, 1992.

THE RISE of State capitalism. The Economist, 21 Jan. 2012. Available at: http://www.economist.com/ node/21543160.

THÜRER, Daniel. International humanitarian law: theory, practice, context. Hague: Hague Academy of International Law, 2011.

TRACHTMAN, Joel P. Trade and ... problems: costbenefit analysis and subsidiarity. European Journal of International Law, v. 9, p. 32-85, 1998.

TZANAKOPOULOS, Antonios. The right to be free from economic coercion. Cambridge International Law Journal, v. 4, p. 616-617, 2015.

UNCTAD. World Investment Report 2011. Available at: http://unctad.org/en/PublicationsLibrary/wir2011_ en.pdf.

UNCTAD. World Investment Report 2015. Available at: http://unctad.org/en/PublicationLibrary/wir2015_ en.pdf.

UNCTAD. World Investment Report 2018. Jun. 6, 2018. Available at: https://unctad.org/en/PublicationsLibrary/wir2018_en.pdf. Access: Nov. 12, 2018.

VINCENTELLI, Ignacio A. The uncertain future of ICSID in Latin America. Dec. 19, 2009. Available at: http:/ / works.bepress.com $/$ cgi $/$ viewcontent.cgi?article $=1000$ \&context=ignacio_vincentelli. Access: Jan. 5, 2019.

WOLFF, Lutz-Christian (ed.). China outbound investments: a guide to law and practice. Hong Kong: CCH Hong Kong Limited, 2011.

WOO, Stu; O’KEEFFE, Kate. Washington asks allies to drop Huawei. The Wall Street Journal, Nov. 23, 2018. Available at: https://www.wsj.com/articles/washington-asks-allies-to-drop-huawei-1542965105. Access: Mar. 31, 2020. 
Para publicar na Revista de Direito Internacional, acesse o endereço eletrônico www.rdi.uniceub.br ou www.brazilianjournal.org.

Observe as normas de publicação, para facilitar e agilizar o trabalho de edição. 